\title{
Protecting Health, Environment AND AGRICULTURE: AUTHORISATION OF GENETICALLY MODIFIED CROPS AND FOOD IN THE UNITED STATES AND THE EUROPEAN UNION
}

\author{
MARgARET Rosso Grossman*
}

\begin{abstract}
Millions of agricultural producers from around the globe now cultivate genetically modified (GM) crops. In both the United States and the European Union, these crops and their food and feed products must be approved after evaluations designed to protect health, the environment, and agriculture. In the United States, federal agencies implement the authorisation process; in the European Community, both Community institutions and Member State authorities play roles. This article describes the comprehensive regulatory provisions that govern GM crops and their products under US and EC law. The article then compares requirements in the two legal systems, with a focus on the process of authorisation, requirements for labelling, and the exercise of precaution in the regulatory process.
\end{abstract}

\section{INTRODUCTION}

In recent years, genetic engineering has resulted in the development of a number of genetically modified organisms (GMOs). Many of these are genetically modified (or genetically engineered) (GM) crops. These crops and their products are used for food and feed. ${ }^{1}$ Though GMOs are subject to

\footnotetext{
* Bock Chair and Professor of Agricultural Law, Department of Agricultural and Consumer Economics, University of Illinois at Urbana-Champaign. This material is based on work supported by the National Institute of Food and Agriculture, US Department of Agriculture, under Hatch Project No ILLU-470-309. Part III of this article is derived in part, with permission, from Margaret Rosso Grossman, 'The Coexistence of GM and Other Crops in the European Union' (2007) 16 Kansas Journal of Law and Public Policy 324 and Part II from a section of a draft article (supported by a grant from the Danish Social Science Research Council) by Margaret Rosso Grossman and Helle Tegner Anker.

1 GMOs and their food products are the focus of this article. Other GMOs produce pharmaceutical compounds and industrial chemicals, which raise additional regulatory issues.
} 
regulatory measures, as they are tested, commercialised, cultivated, and consumed, they are controversial. Many agricultural producers value the traits - herbicide tolerance and insect pest or disease resistance - that GM crops offer, but some consumers and environmentalists have expressed concern about possible threats to human health or the environment. Consumers who doubt the safety of GM foods prefer not to purchase those foods or at least to have the freedom to choose between GM and non-GM food products.

Global cultivation of GM crops has increased rapidly since 1996, when farmers in only six countries grew fewer than three million hectares of these crops. In 2008, farmers in 25 countries grew biotech crops, and the global area of cultivation reached 125 million hectares - a 9.4 per cent increase over 2007. Soybeans, grown on 65.8 million hectares globally, were the principal GM crop, followed by corn, cotton, and canola. In terms of traits, the majority of biotech crops, grown on 79 million hectares, provided herbicide tolerance. Crops with 'stacked' double or triple traits (for example, both herbicide tolerance and insect resistance) grew on 26.9 million acres, and insect resistant varieties, on 19.1 million hectares. $^{2}$

The United States planted half (62.5 million) of the world's total hectares of GM crops. Other countries that grew more than one million hectares in 2008 were Argentina, Brazil, Canada, India, China, Paraguay, and South Africa. About 13.3 million farmers cultivated biotech crops; of these 12.3 million were in developing countries, with the majority of these farmers growing $B t$ cotton $^{3}$ in China (7.1 million), India (5 million), and other developing countries. Indeed, between 1996 and 2008, developing countries have grown an increasing proportion of global biotech crops. ${ }^{4}$

In the United States, biotech crops make up a large majority of soybeans (91 per cent), maize (85 per cent) and cotton (88 per cent). ${ }^{5}$ In the European Union, where only genetically modified maize ( $B t$ maize) has been approved for cultivation, biotech crops are far less prevalent. In 2008, EU farmers cultivated only about 108000 hectares of Bt maize, an increase of 21 per cent over 2007, but still only slightly more than one per cent of total maize

\footnotetext{
${ }^{2}$ Clive James, International Service for the Acquisition of Agri-Biotech Applications, ISAAA Brief 39-2008: Executive Summary, Global Status of Commercialized Biotech/GM Crops: 2008 The First Thirteen Years, 1996 to $2008<$ http://www.isaaa.org/Resources/Publications/ briefs/39/executivesummary/default.html> at 26 October 2009.

${ }^{3} B t$ crops are those that have been genetically engineered to produce a natural insecticide that derives from the $B t$ bacterium, bacillus thuringiensis.

${ }^{4}$ James, above n 2, 4, 8.

${ }^{5}$ National Agricultural Statistics Service (NASS), United States Department of Agriculture, Acreage 24-5 (30 June 2009) <http://usda.mannlib.cornell.edu/usda/current/Acre/Acre-06-302009.pdf $>$ at 26 October 2009.
} 
production. Spanish farmers cultivated the largest number of hectares, and farmers in six other EU Member States - the Czech Republic, Romania, Portugal, Germany, Poland, and Slovakia - also grew biotech maize. ${ }^{6}$ Most EU Member States have no officially recognised GM hectares, and several (for example, Austria, Hungary, France) have attempted to ban cultivation of GM maize. ${ }^{7}$

In both the United States and the European Union, the cultivation of genetically modified crops must coexist with other agricultural systems. ${ }^{8}$ Many producers use conventional or traditional systems and often apply fertilizers and pesticides on their crops. Organic systems do not usually use chemical fertilizers or pesticides, nor do they use GM materials in the production process. When GM, conventional, and organic systems of agricultural production occur in the same geographic region, producers who use organic or conventional systems often want to avoid the 'adventitious presence' of GM material in their crops. The coexistence of GM with traditional and organic farming is therefore a contentious issue, particularly in the European Union.

In the United States, where GM crops make up a large majority of important crops such as soybeans and maize, the rate of adoption indicates that producers are enthusiastic about the benefits of GM crops. Consumers, in contrast, often lack specialised knowledge about biotechnology and its food products. ${ }^{9}$ Nonetheless, according to survey results published in 2008, the majority of US consumers would purchase food developed from biotechnology, especially if it offered specific benefits. About 84 per cent of consumers expressed a favourable or neutral impression of plant biotechnology. Moreover, only one per cent of respondents listed biotechnology as a primary food-safety concern. ${ }^{10}$

Although EC policy favours development of biotechnology, including GM agricultural crops, ${ }^{11}$ those crops and their products have not received a warm

\footnotetext{
${ }^{6}$ James, above n 2, 10-11.

${ }^{7}$ See Part IIIB of this article.

${ }^{8}$ Pew Initiative on Food and Biotechnology, 'Peaceful Coexistence Among Growers of Genetically Engineered, Conventional, and Organic Crops' (Speech delivered at the Pew Initiative on Food and Biotechnology, Washington DC, 1-2 March 2006) 7.

${ }^{9}$ See William K Hallman and W Carl Hebden, 'American Opinions of GM Food: Awareness, Knowledge, and Implications for Education’ (2005) 20(4) Choices 239.

10 International Food Information Council, 2008 Food Biotechnology: A Study of U.S. Consumer Trends (2008), Executive Summary 2, $4<$ http://www.ific.org/research/upload/ Executive-Summary-Biotech-Report_Website-version.pdf> at 26 October 2009.

${ }^{11}$ See generally Commission of the European Communities (EC), Communication from the Commission to the Council, the European Parliament, the European Economic and Social
} 
welcome from governments, producers or consumers. ${ }^{12}$ The EU Commissioner for Agriculture and Rural Development noted that tensions in Europe about GMOs often reflect different goals. ${ }^{13}$ Farmers who focus on enhanced competitiveness see an important role for GMOs, while others prefer traditional or organic practices and fear economic harm from the adventitious presence of GM material. Some European consumers value 'quality production' and products 'linked to traditional practices and geographical origin'; others prefer organic foods. ${ }^{14}$ These values are consistent with the European model of agriculture that balances socioeconomic, as well as environmental and territorial considerations. Some consumers believe that GMOs are not compatible with traditional production. Indeed, an organisation called GMO-free Europe calculated that 289 regions in Europe have declared themselves GM-free or would like to restrict GM crops, and 4567 local governments would also like to restrict GM in their territories. $^{15}$

The following Parts of this article describe the regulatory systems for GMOs and GM food (and feed) in the United States and the European Union and provide a brief comparison of regulatory approaches in the United States and Europe.

Committee and the Committee of the Regions on the Mid Term Review of the Strategy on Life Sciences and Biotechnology COM (2007) 175 final (10 April 2007).

${ }^{12}$ A survey indicated that 58 per cent of Europeans (a majority in most Member States) oppose use of GMOs, though lack of information may contribute to the opposition: European Commission, Attitudes of European Citizens towards the Environment (Special Eurobarometer 295 (2008)), 65-6.

${ }^{13}$ Friends of the Earth Europe, an NGO suspicious of GM technology, asserted that: 'GMO contamination is a new type of pollution created by industry. It involves living and replicating organisms, and because it involves the building blocks of life (genes), is irreversible as well as increasing over time. It can occur at any stage along the food chain as a result of natural processes and human intervention: from seed production, to crop growing, to harvesting, to storage, to transport, to processing and packaging.' Friends of the Earth Europe, Contaminate or legislate? European Commission Policy on 'Coexistence' (2006) $1<\mathrm{http}: / /$ www.foeeurope. org/publications/2006/contaminate_or_legislate.pdf> at 25 March 2009.

${ }^{14}$ M Fischer Boel and J Pröll, 'Concluding Remarks' (Speech delivered at the EU Conference, 'Co-existence of Genetically Modified, Conventional and Organic Crops - Freedom of Choice', Vienna, 5-6 April 2006) <http://ec.europa.eu/agriculture/events/vienna2006/index_ en.htm> at 26 March 2009.

${ }^{15}$ GMO-free Europe, GMO-free Regions and Local Areas in Europe (2009) <http://www.gmofree-regions.org/gmo-free-regions.html $>$ at 26 April 2009. Regions include provinces, prefectures, and departments. In addition, 30,370 individuals are GMO-free. 


\section{Regulation of GM CROPS AND FoOd Products IN THE UNITED STATES}

In the United States, federal policy, laws, and regulations govern testing and commercialisation of crops and food produced through biotechnology. Developers of new GM varieties comply with federal laws and regulations and they participate in consultations recommended by federal agency guidelines. Federal regulation focuses on plant health, environmental protection, and food and feed safety. Though states share these concerns, most states agree that the federal government should bear primary responsibility in these areas, ${ }^{16}$ and states play no statutory role in federal regulation of GM crops. ${ }^{17}$ Many states have enacted general or specific statutory provisions that apply to biotechnology, ${ }^{18}$ but this article focuses on the comprehensive federal regulation of biotechnology.

\section{A Policy}

The 1986 Coordinated Framework for Regulation of Biotechnology established US policy for GMOs, and the Coordinated Framework continues to influence federal policy. Recognising important commercial opportunities from biotechnology, the Coordinated Framework acknowledged questions about the adequacy of existing laws, regulations, and review processes for products of biotechnology. ${ }^{19}$ Ultimately, the Coordinated Framework concluded that products of biotechnology are not fundamentally different from conventional products; that the product, rather than the process, should be regulated; and that regulatory jurisdiction over products of biotechnology (as over traditional products) should be based on their use. ${ }^{20}$

\footnotetext{
${ }^{16}$ Michael R Taylor, Jody S Tick and Diane M Sherman, Tending the Fields: State and Federal Roles in the Oversight of Genetically Modified Crops (Report prepared for the Pew Initiative on Food and Biotechnology, Washington DC, 2004) 21-2.

${ }^{17}$ States receive notice of regulatory activity (for example, when GM plants are moved into specific states), and the USDA provides information to states before field tests. Some state agencies would like to play a more active role in the regulatory process, perhaps in cooperation with federal agencies. For information on state authority, see generally Doug Farquhar and Liz Meyer, 'State Authority to Regulate Biotechnology under the Federal Coordinated Framework' (2007) 12 Drake Journal of Agricultural Law 439.

${ }^{18}$ These laws help to promote specific state interests that include 'health and environmental concerns, capturing the economic benefits of biotechnology, preserving market access, and responding to citizens and stakeholders': Taylor, Tick and Sherman, above n 16, 22.

${ }^{19}$ Office of Science and Technology Policy (OSTP), Coordinated Framework for Regulation of Biotechnology Products, 51 Fed Reg 23,302 (26 June 1986) ('Coordinated Framework'). The OSTP drafted the document with cooperation of administrative agencies.

${ }^{20}$ Ibid 23,303-04.
} 
The Coordinated Framework relied on existing federal laws and agency expertise to govern GMOs. Three federal agencies carry out the most important responsibilities. The US Department of Agriculture (USDA) ensures that GMOs are safe to grow; the US Environmental Protection Agency (EPA) ensures that they are safe for the environment; and the US Food and Drug Administration (FDA, along with the EPA) ensures that they are safe to eat. ${ }^{21}$ Policies articulated in the Coordinated Framework continue to influence Agency action, though new laws and regulations have been enacted since $1986 .^{22}$

In recent years, development and field testing of new GM varieties have increased risks and triggered the need for new regulatory measures. A 2002 policy document outlined plans of the lead agencies to strengthen regulation and enhance oversight. $^{23}$ The USDA had already made field testing requirements for permits more stringent for GMOs intended for pharmaceutical or industrial products (rather than commodity crops) and also planned to update its GM regulations. ${ }^{24}$ The FDA planned to publish guidelines to encourage the early evaluation of crops with new non-pesticidal proteins so that new crops would not raise food safety issues - caused, for example, by toxins or allergens that might escape into seeds, commodities, or food. The EPA planned to publish guidance on the conduct of safety reviews of low-level residues and containment controls during field trials and to review its requirements for experimental use permits and containment

${ }^{21}$ Ibid 23,309-50, where agencies set out their policies for GMOs. In addition to the three leading agencies, the Coordinated Framework included policy from the Occupational Safety and Health Administration for safety and health of workers and from the National Institutes of Health for conduct of research. Federal research supports the federal regulatory structure.

22 The Government Accountability Office recommended improvement in coordination of agency efforts and monitoring of GM crops: Government Accountability Office, Genetically Engineered Crops: Agencies Are Proposing Changes to Improve Oversight, but Could Take Additional Steps to Enhance Coordination and Monitoring (GAO-09-60, November 2008) ('GAO, GE Crops').

${ }^{23}$ Office of Science and Technology Policy, Proposed Federal Actions to Update Field Test Requirements for Biotechnology Derived Plants and to Establish Early Food Safety Assessments for New Proteins Produced by Such Plants, 67 Fed Reg 50,578 (2 August 2002) ('OSTP, 2002 Policy'). Three principles form the basis of the 2002 regulatory proposals. First, the level of confinement for a field test should be consistent with the level of risk to the environment and health. Second, confinement measures for GM traits or proteins that present an unacceptable or unknown risk should be strict, and GM materials from the tests should be prohibited in seeds, commodities, and other products. Third, out-crossing and commingling should be minimised, but low levels of biotechnology-derived gene presence from field tests might be found acceptable.

${ }^{24}$ Ibid 50,580. USDA amendments would reflect recommendations from a National Research Council report, Environmental Effects of Transgenic Plants: The Scope and Adequacy of Regulation (2002). This article does not focus on crops that produce pharmaceutical or industrial compounds, which are subject to stricter regulation. 
controls to minimise gene flow from field trials. ${ }^{25}$ These proposals were designed to reduce the unintended presence of low levels of GM material in seeds, commodities and food until safety standards had been met, and thus to protect public health and the environment and to increase public confidence in the effectiveness of regulatory oversight of GM foods. ${ }^{26}$ Though some of these proposals have been carried out, others are still in progress.

\section{B USDA - Plant Protection Act}

The United States Department of Agriculture regulatory framework is science-based and focuses on safe development and use of GM plants. The USDA's Animal and Plant Health Inspection Service (APHIS) and its Biotechnology Regulatory Services govern interstate movement, import, field testing and eventual release of GM plants

The USDA regulates GM plants under the Plant Protection Act of 2000, ${ }^{27}$ which authorises the Agency to restrict the import, export, and movement in commerce of plant pests. Under the broad definition of 'plant pest' in APHIS regulations, ${ }^{28}$ most GMOs are materials that could harbour a plant pest and are therefore 'regulated articles' subject to USDA jurisdiction. ${ }^{29}$ APHIS regulations govern the introduction of regulated articles into the environment through field trials and their movement in interstate commerce. GMOs must be evaluated and determined to be 'unregulated' before they can be sold in commerce. $^{30}$

\section{$1 \quad$ Field Trials}

Field trials take place while a new crop is still a regulated article under the Plant Protection Act. Since 1993, the majority of field trials have followed the notification process, ${ }^{31}$ designed for plants that do not present novel plant

25 OSTP, 2002 Policy, above n 23, 50,579. The EPA planned to continue to use its procedures that govern residues of pesticidal proteins in foods and to urge those developing new crops to seek approval for residues early in the development process.

${ }^{26}$ Ibid 50,578-9.

277 USCA §§ 7701-7772 (West 1999 \& Supp 2009); § 7711 authorizes regulation of plant pests. The Plant Protection Act replaced the Plant Pest and Plant Quarantine Acts, on which the USDA had relied for authority.

287 CFR (Code of Federal Regulations) § 340.1 (2009); see also 7 USC § 7702(14) (2006).

${ }^{29}$ A regulated article is an 'organism which has been altered or produced through genetic engineering, if the donor organism, recipient organism, or vector or vector agent ... meets the definition of plant pest ...': 7 CFR $\S 340.1$ (2009).

${ }^{30}$ See the discussion in Part IIB2 of this article.

31 See USDA-APHIS Biotechnology Regulatory Services, User's Guide: Notification (5 February 2008) <http://www.aphis.usda.gov/brs/pdf/Notification_Guidance.pdf> at 25 March 
risks. $^{32}$ Regulations prescribe the procedure for notifying APHIS and the information required, including the location and size of the field test and technical data about the regulated article. ${ }^{33}$ Performance standards for field trials under the notification procedure help to ensure that the field trial will not cause environmental or economic harm. Anyone conducting a field trial must allow inspection of facilities and records and report results of field tests and any unusual occurrence to APHIS. ${ }^{34}$

The more rigorous permit procedure applies to experimental releases of GM plants that pose higher risks, for example, plants modified with certain human or animal genetic material and those that produce industrial or pharmaceutical compounds. $^{35}$ The permit requires detailed technical data and specific information about experimental design, geographic location, plans to prevent escape and dissemination, and final disposal. ${ }^{36}$ APHIS reviews the application $^{37}$ and, as required by the National Environmental Policy Act (NEPA), ${ }^{38}$ prepares an environmental assessment followed, if necessary, by an environmental impact statement. After review of the application and accompanying data, APHIS will grant or deny (with reasons and subject to appeal) the permit. The permit will include conditions to ensure that introduction of the plant will not disseminate or establish plant pests. The permit holder must report the results of field tests and notify APHIS promptly

2009. Between 1987 and 2007, APHIS authorised almost 19,000 notifications and 4,300 permits; over 13,000 were for field trials: GAO, GE Crops, above n 22, 11.

327 CFR § 340.3(b)(1)-(6) (2008). Plants eligible for the notification process must not be listed as a noxious weed and the GM may not encode products for pharmaceutical or industrial use. Other technical requirements apply.

337 CFR § 340.3(d)(2) (2008). APHIS acknowledges the notification within 30 days (340.3(e)(4)). Field tests that will last for more than one year require permits. APHIS, Policy Statement Regarding Releases of Perennials under Notification <http://www.aphis.usda.gov /brs/pdf/BRS_Perennials_Statement.pdf > at 25 March 2009.

347 CFR § 340.3(c),(d)(5),(6) (2008).

357 CFR § 340.3(b)(4)(iii) (2008). A person whose notification results in a denial of permission may also apply for a permit: at $\S 340.3(\mathrm{e})(5)$.

367 CFR § 340.4(b)(1)-(14) (2008).

377 CFR § 340.4(b) (2008). APHIS sends the completed permit application (but without trade secrets or confidential business information), along with its initial review, to the relevant state department of agriculture: at $\S 340.4(\mathrm{~b})$.

${ }^{38} 42$ USC §§ 4321-4370f (2006). NEPA requires federal agencies to integrate environmental values into the process of decision making. Federal agencies must prepare a detailed environmental impact statement for 'major Federal actions significantly affecting the quality of the human environment’: at § 4332(2)(C). 
of accidental or unauthorised releases, unexpected characteristics of the organism, and other unusual occurrences. ${ }^{39}$

\section{Petitions for Deregulation}

When field tests indicate that a new GM variety is not a plant pest and poses no threat to agriculture or the environment, the variety is ready to be commercialised. The next step is a petition for determination of 'nonregulated status'. ${ }^{40}$ The petition explains why the organism should no longer be regulated. The applicant provides detailed information about the organism, including information that would be 'unfavorable to a petition'. ${ }^{41}$ Results of field tests are an important part of the petition, and data must substantiate the conclusion that the GM plant is 'unlikely to pose a greater plant pest risk than the unmodified organism from which it was derived'. ${ }^{42}$

APHIS reviews the risk of the regulated variety to determine whether it can be released safely into the environment. Review includes an environmental assessment, required under NEPA. If the assessment results in a finding of no significant impact, ${ }^{43}$ no environmental impact statement is required; if the

397 CFR § 340.4(f) (2008). More stringent requirements accompany permits for GE crops with pharmaceutical and industrial uses. See Biotechnology Regulatory Services, United States Department of Agriculture, Guidance for APHIS Permits for Field Testing or Movement of Organisms Intended for Pharmaceutical or Industrial Use (July 2008) $<$ http://www.aphis.usda.gov/brs/pdf/Pharma_Guidance.pdf> at 24 March 2009. In September 2007, APHIS' Biotechnology Regulatory Services announced a new program to help applicants approved to introduce GM organisms 'to develop sound management practices and to enhance compliance' with APHIS regulations and permit requirements: Biotechnology Regulatory Services, APHIS, 'The Biotechnology Quality Management System' (Factsheet, June 2008) <http://www.aphis.usda.gov/publications/biotechnology/content/printable_ version/fs_qms_brs_08.pdf > at 20 October 2009. In January 2009, APHIS introduced a pilot project under which five volunteer participants will develop quality management systems to manage field releases: APHIS, 'USDA Launches Biotechnology Quality Management System Pilot Project' (Press Release, 16 January 2009).

407 CFR § 340.6 (2008).

417 CFR § 340.6(b) (2008). Data requirements include experimental data, unpublished studies, and scientific literature. The applicant must describe the conventional plant, the regulated article (the GM plant), and differences between them.

427 CFR § 340.6(c)(4) (2008). Data to meet this standard includes 'Plant pest risk characteristics, disease and pest susceptibilities, expression of the gene product, new enzymes, or changes to plant metabolism, weediness of the regulated article...[and other information]. Any information known to the petitioner that indicates that a regulated article may pose a greater plant pest risk than the unmodified recipient organism shall also be included': at $\S$ 340.6(c)(4).

${ }^{43}$ APHIS prepares a preliminary assessment, then accepts and reviews public comments before preparation of the final assessment. Further NEPA analysis to address concerns about the use of regulated products will be done by the agency that reviews or approves the product, taking into account the APHIS review. 
variety may have a significant impact, APHIS must prepare an environmental impact statement. ${ }^{44}$ On the basis of the environmental assessment or environmental impact statement and other documentation, APHIS makes the determination of nonregulated status or, less often, denies the petition. ${ }^{45}$ If the petition is granted, the organism can move freely in commerce, provided that it also meets the regulatory requirements of the FDA and EPA. As of February 2009, APHIS had granted 75 petitions, and 14 were pending. ${ }^{46}$

Because nonregulated status means that a variety poses no environmental or agricultural risk, APHIS no longer has authority over that variety. Should it later become a plant pest, however, it will again be subject to regulation. ${ }^{47}$

\section{APHIS Policy for Low-Level Gene Mixing}

Plant breeding, both in conventional and GM plants, sometimes results in 'low-level mixing of genes and gene products from unintended plant sources'. ${ }^{48}$ Moreover, natural processes (pollen movement) or human actions (for example, field testing or seed production) may introduce unauthorised GMOs into other products. Therefore, on the basis of practical experience, APHIS has articulated a policy for low-level gene mixing.

\footnotetext{
${ }^{44}$ A recent court decision held that the failure of APHIS to prepare an environmental impact statement for a GM feed, glyphosate-tolerant alfalfa, did not comply with NEPA. The court vacated APHIS' determination of nonregulated status and ordered APHIS to prepare an environmental impact statement before it acts on the petition for deregulation. The court also enjoined planting of the alfalfa: Geertson Seed Farms, Inc v Mike Johanns, 2007 WL 518624, 2007 WL 1302981 (ND Cal) ('Geertson'). In September 2008, the US Court of Appeals for the Ninth Circuit affirmed the injunction against planting the alfalfa, pending APHIS' preparation of the environmental impact statement and action on the petition to deregulate: 541 F3d 938 (9th Cir 2008), amended and superseded by 570 F3d 1130 (9th Cir 2009). For more information on Geertson and other decisions involving GMOs and NEPA, see Margaret Rosso Grossman, 'Genetically Modified Food and Feed and the US National Environmental Policy Act' (2007) 3(6) European Feed and Food Law Review 373. See also Delaware Audubon Soc Inc v Secretary US Department of Interior, 612 F Supp 2d 442 (D Del 2009), enjoining cultivation of GM crops at Prime Hook National Wildlife Refuge until an environmental assessment or environmental impact statement is completed.

457 CFR § 340.6(d),(f) (2008).

${ }^{46}$ The varieties, with links to relevant documents, are listed at <http://www.aphis.usda.gov/ brs/not_reg.html> at 24 March 2009. The earliest determination of non-regulated status was Calgene's Flavr Savr tomato (1992).

${ }^{47}$ A GAO study recommended that the USDA, along with the EPA and FDA, develop a strategy to monitor GM crops that have been commercialised for effects on the environment, food safety, and traditional (non-GM) agriculture. The agencies plan to discuss a coordinated strategy for monitoring deregulated crops: GAO, GE Crops, above n 22, 24-34, 48.

48 APHIS, USDA, APHIS Policy on Responding to the Low-Level Presence of Regulated Genetically Engineered Plant Materials, 72 Fed Reg 14,649 (29 March 2007) ('APHIS, LowLevel Presence').
} 
Regulatory requirements minimise the likelihood of low-level presence of regulated GMOs in other crops. APHIS, in close cooperation with the EPA and FDA, responds to occurrences with 'remedial action that is appropriate to the level of risk and warranted by the facts in each case'. ${ }^{49}$ When an incident would result in introduction or dissemination of a plant pest or threaten plant health or the environment, APHIS will require remediation measures, using its authority under the Plant Protection Act. ${ }^{50}$ APHIS will generally not require remedial measures if the regulated material comes from a plant that meets requirements for notification of field tests (and thus poses little risk) or if the plant is sufficiently similar to another plant that APHIS has already deregulated and therefore poses no significant safety risk to plant health or the environment. ${ }^{51}$

\section{$4 \quad$ Proposed Regulations}

In July 2007, APHIS outlined possible amendments to its regulations for environmental release of GMOs and requested comments from the public. ${ }^{52}$ In connection with its regulatory review, APHIS compiled a list of 'lessons learned' from its experience in regulating biotechnology. ${ }^{53}$ In the May 2008 Farm Bill, Congress directed the USDA to 'take action on each issue identified in the document' within eighteen months. ${ }^{54}$

${ }^{49}$ Ibid 14,650. The few reported unauthorised releases of GM crops have led to costly food recalls and lost trade: GAO, GE Crops, above n 22, 3 and 14-24.

507 USC $\S 7714$ (2006). APHIS regulatory actions do not preclude the EPA or FDA from using their legal authority to protect food safety, health and the environment: APHIS, Low-Level Presence, above n 48, 14,651.

${ }^{51}$ APHIS, Low-Level Presence, above n 48, 14,651. This policy applied in February 2008 and December 2008, when low levels of unauthorised GM corn (3 seeds per 1000) and GM cotton (small quantities) were found in other products: 'USDA, EPA, and FDA Statement on Genetically Engineered Corn "Event 32"' (Press Release, 22 February 2008); 'FDA, EPA and USDA Conclude that Accidental Release of Genetically Engineered Cotton Poses No Safety Risk to Humans or Animals' (Press Release, 3 December 2008).

52 APHIS, Introduction of Genetically Engineered Organisms, Draft Programmatic Environmental Impact Statement - July 2007, Docket APHIS-2006-0112 $<$ http://www.regulations.gov> ('APHIS, Draft EIS'); APHIS, Introduction of Organisms and Products Altered or Produced Through Genetic Engineering, 71 Fed Reg 39,021, 39,022 (17 July 2007).

${ }^{53}$ USDA, 'Lessons Learned and Revisions under Consideration for APHIS' Biotechnology Framework' (October 2007) (listing nine lessons and considerations for enhancing regulation).

${ }^{54}$ Food, Conservation and Energy Act of 2008, Pub L No 110-246, § 10,204. The USDA must consider establishing a system of risk-based categories for regulated articles, means of identification (including retention of seed samples), and standards for isolation and containment. The USDA must also consider requiring permit holders to maintain a 'positive chain of custody' and to keep records. 
In response to this congressional mandate, APHIS published comprehensive proposed regulations in October 2008. Its proposals, already under consideration when Congress required prompt regulatory action, are designed

to respond to emerging trends in biotechnology, to address the current and future needs of the agency, to continue to ensure a high level of environmental protection, to improve regulatory processes so that they are more transparent to stakeholders and the public, to more efficiently use agency resources and to eliminate unnecessary regulatory burdens. ${ }^{55}$

APHIS proposed to expand its regulatory oversight under the Plant Protection Act beyond plant pests to include noxious weeds and biological control organisms. ${ }^{56}$ In light of the increased variety of GM organisms, APHIS proposed to revise its permit system, establishing four permit categories (based on risk of persistence and potential harm) for environmental releases of GM plants and eliminating the notification procedure. New regulations would revise procedures for permit applications and establish permit conditions and obligations. $^{57}$

In addition, proposed amendments would adapt the system of petitions for non-regulated status to the broadened scope of regulation and focus on whether the GMO is 'unlikely to be a plant pest or noxious weed'. ${ }^{58}$ APHIS also proposed a procedure for revoking an approval of non-regulated status and new measures to strengthen compliance (including stricter requirements for record keeping) and enforcement. APHIS may also enact a regulation on

${ }^{55}$ USDA, APHIS, Importation, Interstate Movement, and Release into the Environment of Certain Genetically Engineered Organisms 73 Fed Reg 60,008, 60,009 (9 October 2008), corrected at 73 Fed Reg 66,563 (10 November 2008), to be codified at 7 CFR pt 340 ('APHIS, 2008 Proposed Regulations'). The proposed regulations also respond to the recommendations in Office of the Inspector General, USDA, Audit Report: Animal and Plant Health Inspection Service Controls over Issuance of Genetically Engineered Organism Release Permits, Audit 50601-8-Te (2005) and to comments on the Draft EIS above n 52. The comment period on the proposal ended 31 June 2009: 74 Fed Reg 16,797 (13 April 2009).

${ }^{56}$ APHIS, 2008 Proposed Regulations, above n 55, 60,011-15. The Plant Protection Act defines noxious weed to include 'any plant or plant product that can directly or indirectly injure or cause damage to crops ... or other interests of agriculture, irrigation, navigation, the natural resources of the United States, the public health, or the environment': 7 USC § 7702(10) (2006). Biological control organisms include 'any enemy, antagonist, or competitor used to control a plant pest or noxious weed': at § 7702(2).

${ }^{57}$ APHIS, 2008 Proposed Regulations, above n 55, 60,016-23. Review of notifications, even under current regulations, is similar to review of permit applications. APHIS proposed only minor changes to the permit process for interstate movement and import.

${ }^{58}$ Ibid 60,023-5, 60,047. Organisms already non-regulated will be approved automatically under the proposed new regulations. 
low-level presence of regulated materials, designed to implement its 2007 policy statement on remediation. ${ }^{59}$

\section{EPA Regulation}

The EPA regulates GM plants that express pesticidal substances as pesticides under the Federal Insecticide, Fungicide, and Rodenticide Act (FIFRA). ${ }^{60}$ The Agency also regulates pesticide residues in foods under the Food, Drug, and Cosmetic Act (FDCA). ${ }^{61}$ The EPA addresses food safety issues associated with pesticides, and the FDA addresses other food safety issues (for example, compositional changes in food). ${ }^{62}$

In 1994, the EPA issued a Policy Statement and Proposed Rules. ${ }^{63}$ Though the Agency then started to regulate under FIFRA and the FDCA, it enacted its regulatory framework only in 2001, with rules that established criteria, procedures, and requirements under both FIFRA and the FDCA. ${ }^{64}$ In 2007, a new guidance document focused on small-scale field studies and low-level presence of GM pesticidal materials in food. ${ }^{65}$

${ }^{59}$ Ibid 60,025-26. See above text at nn 48-51. A proposed regulation would allow APHIS to exempt privileged or confidential business information from release under the Freedom of Information Act, 5 USCA § 552 (West 2007 \& Supp 2009).

607 USCA §§ 136-136y (West 1999 \& Supp 2009).

${ }^{61} 21$ USCA § 346a (West 1999 \& Supp 2009). At the time of the 1992 Policy Statement, pesticide residues were regulated as food additives.

${ }^{62}$ FDA, Statement of Policy: Foods Derived from New Plant Varieties, 57 Fed Reg 22,984, 23,005 (29 May 1992) ('FDA, 1992 Policy'). The FDA has authority for substances intended to enhance plant resistance to chemical herbicides, like glyphosate. Some instances, however, would require expertise of both the EPA and FDA, and questions of jurisdiction are to be raised with the EPA.

${ }^{63}$ EPA, Plant Pesticides Subject to the Federal Insecticide, Fungicide and Rodenticide Act and the Federal Food, Drug, and Cosmetic Act; Proposed Rule, 59 Fed Reg 60,496 (23 November 1994), to be codified at 40 CFR pts 152, 174, 180. The EPA published other proposals at 59 Fed Reg 60,519, 60,535, 60,542, and 60,545 (23 November 1994).

${ }^{64}$ EPA, Regulations under the Federal Insecticide, Fungicide, and Rodenticide Act for PlantIncorporated Protectants (Formerly Plant-Pesticides), 66 Fed Reg 37,772 (19 July 2001), codified at 40 CFR pts 152 and 174 ('EPA, 2001 FIFRA Regulation').

${ }^{65}$ EPA, Pesticide Registration (PR) Notice 2007-2: Guidance on Small-Scale Field Testing and Low-Level Presence in Food of Plant-Incorporated Protectants (PIPs) (EPA Doc. EPA-HQOPP-2007-0654-0001, 2007) <http://www.epa.gov/PR_Notices/pr2007-2.htm> at 24 March 2009 ('EPA, Notice 2007-2'). The guidance document set out policy established in FIFRA, FDCA, and EPA regulations. It does not bind the EPA or others, and the EPA can depart from the guidance: at 7 . 


\section{Plant Incorporated Protectants (PIPS) - FIFRA}

Plant incorporated protectants (PIPs) fit within the FIFRA definition of pesticides because they are introduced into plants as a means of 'preventing, destroying, repelling, or mitigating any pest' ${ }^{66}$ A common example of a PIP is the pesticide frequently used in GM crops, Bt (bacillus thuringiensis).

No pesticide can be marketed and used in the United States until it has been registered. ${ }^{67}$ A pesticide can be registered if the applicant can show that its composition warrants the registrant's claims, its labelling complies with FIFRA and, when used in accordance with normal practice, it does not 'cause unreasonable adverse effects on the environment'. ${ }^{68}$

The EPA uses the FIFRA registration system to collect data on the safety, efficacy and environmental effects of PIPs. ${ }^{69}$ Field tests of unregistered PIPs, authorised by experimental use permits, allow the developer to gather information for its own use and to support registration. ${ }^{70}$ If a field test is reasonably expected to result in a food residue, the EPA may establish a temporary food tolerance (a legal limit on the maximum amount of the substance in or on food) under the FDCA before issuing the permit. ${ }^{71}$ Some field tests 'are presumed not to involve unreasonable adverse effects ${ }^{\text {,72 }}$ and

\footnotetext{
${ }^{66} 7$ USC § 136(u) (2006). The EPA defines PIP as: 'a pesticidal substance that is intended to be produced and used in a living plant, or in the produce thereof, and the genetic material necessary for production of such a pesticidal substance. It also includes any inert ingredient [such as selective markers used to ensure the active ingredient is inserted into the plant] contained in the plant, or produce thereof': 40 CFR $\S 174.3$ (2008). See EPA, Notice 2007-2, above n 65,1 .

677 USCA § 136a (West 1999 \& Supp 2009). Establishments where pesticides are produced must also be registered under FIFRA, § 136e. The EPA can exempt from regulation a pesticide that is regulated by another federal agency or 'of a character which is unnecessary to be subject to’ FIFRA: § 136w(b). See also EPA, 2001 FIFRA Regulation, above n 64, 37,773 (interpreting EPA authority to exempt pesticides).

687 USCA § 136a(c)(5) (West 1999 \& Supp 2009). See § 136(bb): 'The term 'unreasonable adverse effects on the environment' means (1) any unreasonable risk to man or the environment, taking into account the economic, social, and environmental costs and benefits of the use of any pesticide, or (2) a human dietary risk from residues that result from a use of a pesticide in or on any food inconsistent with the standard under section 346a of title 21.'

${ }^{69}$ Data requirements are extensive and include product characteristics, mammalian toxicity, gene flow assessment, risk to non target organisms, environmental fate, and insect resistance. See generally EPA, Introduction to Biotechnology Regulation for Pesticides: Guidance Document (2007) 6-25 <www.epa.gov/oppbppd1/biopesticides/regtools/biotech-regprod.htm> at 24 March 2009 ('EPA, Intro to Biotech Regulation').

707 USC § 136c (2006); 40 CFR pt 172 (2008). In issuing permits, the EPA must determine that the experimental use will not result in 'unreasonable adverse effects' on human health or the environment: 7 USC § 136c(d) (2006); 40 CFR § 172.10(a) (2008).

${ }^{71} 7$ USC $\S 136 c(b)$ (2006).

7240 CFR § 172.3(a) (2008).
} 
therefore do not require a permit. Laboratory or greenhouse tests are presumed to be exempt. A small-scale test on a cumulative total of no more than ten acres of land per target pest does not require an experimental use permit, but any food or feed crops involved in the test must be destroyed or eaten by experimental animals unless the EPA has established a food tolerance (or exemption) for residues. ${ }^{73}$

The EPA encourages those conducting field trials to consult with the Agency to discuss confinement of the tested PIP. Physical or biological controls that comply with APHIS requirements will generally satisfy the EPA. As a result of the consultation, the EPA may recommend that the developer seek a temporary food tolerance, or the Agency may require an experimental use permit. $^{74}$

In April 2007, the EPA sought public comments on possible new regulations for PIPs, which are governed in part by general regulations that apply to all pesticides. ${ }^{75}$ Because PIPs are produced and used in a living plant, they differ from pesticides intended for external physical application. ${ }^{76}$ EPA regulations that govern the registration of pesticide establishments and pesticide production are not completely appropriate for PIPs, which present unique regulatory issues. ${ }^{77}$ Therefore the EPA plans to codify new data requirements for pesticide registration of PIPs to reflect current scientific advances and to 'improve the Agency's ability to make regulatory decisions about human health and environmental effects of PIP pesticides to better protect wildlife, the environment and people'. ${ }^{78}$

\footnotetext{
${ }^{73} 40$ CFR § 172.3(b),(c) (2008). The EPA requires notification and approval (or a permit) for a small scale test of certain microbial pesticides, including those 'whose pesticidal properties have been imparted or enhanced by the introduction of genetic material that has been deliberately modified': 40 CFR § 172.45(c)(1) (2008); EPA, Intro to Biotech Regulation, above $n$ 69, 3-4.

${ }^{74}$ EPA, Notice 2007-2, above n 65, 2.

75 EPA, Plant-Incorporated Protectants; Potential Revisions to Current Production Regulations, 72 Fed Reg 16,312 (4 April 2007).

${ }^{76}$ Ibid 16,312-13. The EPA believes that PIPs usually present lower risk than chemical pesticides.

${ }^{77}$ For example, regulations that require reporting of volume or weight of pesticides are inappropriate for PIPs in living plants: 40 CFR pt 167 (2008).

${ }^{78}$ EPA, Statement of Priorities, 72 Fed Reg 69,922, 69,939 (10 December 2007). The planned regulations, with no legal deadline but a May 2009 completion goal, will amend 40 CFR pts 158 and 174. See also 72 Fed Reg 19,590 and 19,640 (18 April 2007).
} 


\section{Pesticide Residues - FDCA}

The FDCA governed pesticide residues in the same way as other food additives until the 1996 Food Quality Protection Act ${ }^{79}$ removed pesticide residues from the definition of food additives and from the controversial food additive Delaney Clause. ${ }^{80}$ The FDCA now provides that raw or processed food or feed that contains pesticide chemical residues is considered adulterated and cannot be moved in interstate commerce, unless the residue complies with an established tolerance or has been exempted from the tolerance requirement. ${ }^{81}$ Residues of PIPs in foods (including food produced during field tests) are subject to this requirement.

The EPA sets pesticide tolerances for foods (or establishes an exemption), and the FDA enforces those pesticide tolerances. The EPA may establish a tolerance only if it is 'safe'. ${ }^{82}$ The EPA may grant exemptions, either temporary or permanent, from the tolerance requirement if tests indicate that the pesticidal protein is neither toxic nor allergenic and there is 'a reasonable certainty that no harm will result' from aggregate exposure. ${ }^{83}$ Scientific data must support requests for tolerances or exemptions. ${ }^{84}$ By regulation, the EPA has granted both temporary and permanent exemptions to PIPs in GM crops, for example, various proteins associated with $B t$ crops. $^{85}$

\section{FDA - The Food Drug and Cosmetic Act}

The Food, Drug, and Cosmetic Act (FDCA) ${ }^{86}$ authorises the FDA to regulate the safety of food and feed, including non-pesticidal GM foods from new plant varieties. In regulating food safety, the FDA relies primarily on

\footnotetext{
${ }^{79}$ Pub L No 104-170, 110 Stat 1489, 1513 (3 August 1996).

${ }^{80}$ Delaney clauses prohibit FDA approval of substances that contain carcinogens. See 21 USC $\S \S 348(\mathrm{c})(3)(\mathrm{A})$ (food additives), 360b(d)(1)(H) (color additives), 379e(b)(5)(B) (animal drugs) (2006). See Les $v$ Reilly, 968 F2d 985 (9th Cir 1992).

${ }^{81} 21$ USC § 346a(a)(1) (2006). See also EPA, Notice 2007-2, above n 65, 3.

${ }^{82} 21$ USC § 346a(b)(2)(A)(i) (2006). Safe means 'a reasonable certainty that no harm will result from aggregate exposure to the pesticide chemical residue, including all anticipated dietary exposures and all other exposures for which there is reliable information': at $\S$ $346 a(b)(2)(A)(i i)$.

${ }^{83} 21$ USC § 346a(c)(2)(A)(i),(ii) (2006). The risk to infants and children must be considered, but benefits from the use of the pesticide cannot be considered.

${ }^{84}$ EPA, Notice 2007-2, above n 65, 6-7. See 40 CFR $\S 174.507$ (2008) (exempting residues of nucleic acids that are part of PIPs).

${ }^{85}$ See 40 CFR § 174.501-528 (2008) for exemptions.

${ }^{86} 21$ USC §§ 301-399 (West 1999 \& Supp 2009). Meat and poultry products are regulated, in the main, by the USDA.
} 
provisions that prohibit adulteration of food and govern food additives. ${ }^{87}$ The FDA insists that those who introduce a new food have legal responsibility to evaluate its safety and to ensure that it meets the requirements of the FDCA. ${ }^{88}$ FDA policy for GM foods is influenced by the Agency's belief that GM varieties and their food products 'are as safe and nutritious as their traditional counterparts'. 89

\section{FDA Policy}

Because new plant varieties had been developed safely, the FDA did not routinely conduct pre-market safety reviews of new foods derived from plants. In its 1992 Policy Statement, the Agency adopted a similar approach to GM foods. ${ }^{90}$ The FDA expected most transferred genetic material to be safe, but genetic modification could cause changes - for example, in structure, function, or composition - that require evaluation to ensure food safety. ${ }^{91}$ If necessary to protect public health, the FDA has authority to require premarket review and approval of new foods. ${ }^{92}$

The FDA indicated that it would focus on the food product, rather than the process by which the food was produced:

The regulatory status of a food, irrespective of the method by which it is developed, is dependent upon objective characteristics of the food and the

\footnotetext{
${ }^{87} 21$ USC §§ 342, 348 (2006).

${ }^{88}$ See FDA, 1992 Policy, above n 62, 22,990.

${ }^{89}$ Keith T Atherton, 'Safety Assessment of Genetically Modified Crops' (2002) 181-82 Toxicology 421, 421.

${ }^{90}$ FDA, 1992 Policy, above n 62, 22,988. Section VII of the policy document focuses on
} scientific conditions and includes flow charts to help producers decide if a new food presents no safety concerns, is an unacceptable new variety, or if the FDA should be consulted.

${ }^{91}$ These include unexpected effects (for example, introduction of undesirable traits), higher levels of toxicants than in other varieties of the same species, alteration in nutrient levels, introduction of new substances (proteins, carbohydrates, fats, oils) that differ significantly in composition, allergenicity, presence of antibiotic resistance markers, production of non-food chemicals (for example, pharmaceuticals) in new plants: FDA, 1992 Policy, above n 62, 22,986-88. Animal feeds raise particular issues, because a single food type may make up a majority of animals' diets and because animals consume parts of plants that humans do not eat: at 22,988.

${ }^{92}$ Ibid 22,988-90, citing 21 USC § 342(a)(1) (2006) as the source of authority. The Flavr Savr tomato (FDA Docket No 91A-0330, developed by Calgene, Inc) was the first genetically engineered food reviewed by the FDA. At Calgene's request, the FDA reviewed the Flavr Savr tomato stringently to determine whether it was as safe as other tomatoes; the agency concluded that no significant safety differences existed. See FDA, Calgene, Inc; Availability of Letter Concluding Consultation, 59 Fed Reg 26,647 (23 May 1994). The EPA also approved the tomato's marker gene, which was not generally recognised as safe, as a food additive: at 26,700. 
intended use of the food (or its components).... [K]ey factors in reviewing safety concerns should be the characteristics of the food product, rather than the fact that the new methods are used. ${ }^{93}$

Therefore the FDA relied on its existing regulatory regime to ensure the safety of foods and food ingredients from new plant varieties.

The FDA's Policy Statement indicated that its approach was 'consistent with the concepts of substantial equivalence of new foods' articulated by the Organisation for Economic Co-operation and Development and principles for assessment of food safety established by the UN Food and Agriculture Organization and the World Health Organization. ${ }^{94}$ Substantial equivalence is 'an internationally recognized standard that measures whether a biotech food or crop shares similar health and nutritional characteristics with its conventional counterpart'. ${ }^{95}$ It is not a safety assessment, but involves a 'comparative approach and embodies the idea that existing traditionally produced foods can serve as a reference to evaluate the safety of genetically modified foods'. ${ }^{96}$ That is, if a GM food product and its conventional counterpart do not differ in nutritional (or anti-nutritional) components, the GM product is considered to be substantially equivalent. ${ }^{97}$ The FDA subjects to premarket review only foods that lack substantial equivalence - that is, foods with characteristics that carry higher risk (for example, toxin levels or a new substance). ${ }^{98}$

The FDA proposed, but may never implement, a requirement that it receive notice at least 120 days before commercial distribution of most bioengineered foods, including those derived from new GM plants with pesticidal

\footnotetext{
${ }^{93}$ FDA, 1992 Policy above n 62, 22,984-85. A National Academy of Sciences report agrees with the FDA: a 'policy to assess products based exclusively on their method of breeding is scientifically unjustified' - NAS, Safety of Genetically Engineered Foods: Approaches to Assessing Unintended Health Effects (2004) 9.

${ }^{94}$ FDA, 1992 Policy, above n 62, 22,992 (referring to OECD and FAO/WHO documents).

${ }^{95}$ Council for Biotechnology Information, Substantial Equivalence in Food Safety Assessment (2001) $1<\mathrm{http}: / / w w w . w h y b i o t e c h . c o m / h t m l / p d f / S u b s t a n t i a l \_E q u i v a l e n c e . p d f>$ at 25 March 2009.

${ }^{96} \mathrm{H}$ A Kuiper et al, 'Substantial Equivalence - an Appropriate Paradigm for the Safety Assessment of Genetically Modified Foods?' (2002) 181-82 Toxicology 427, 427.

${ }^{97}$ Council for Biotechnology Information, above n 95, 1. One scholar asserted that the FDA's use of substantial equivalence in the 1992 Policy Statement 'shifted the burden of proof back to the government for the vast majority of GM foods': Thomas O McGarity, 'Seeds of Distrust: Federal Regulation of Genetically Modified Foods' (2002) 35 University of Michigan Journal of Law Reform 403, 484.

${ }^{98}$ In analysing gene products, the first step is evaluation for allergenicity, acute toxicities, and major 'compositional components'. The second step, if the protein is safe, focuses on substantial equivalence: Council for Biotechnology Information, above n 95, 1.
} 
substances. This measure would allow the FDA to ensure that plant-derived bioengineered foods comply with the FDCA, particularly in situations where unintended changes in foods might raise questions of harm to health or misbranding. Because most modifications would not raise such questions, the FDA did not plan to require premarket approval for all GM foods or to require special labels. ${ }^{99}$ At the same time, the FDA published a Draft Guidance on voluntary labelling, ${ }^{100}$ which has not been finalised.

\section{Guidance Documents}

The FDA often communicates with its own staff, industry, and the public through guidance documents. These documents, less formal than regulations, reflect the Agency's current thinking, but do not legally bind the FDA or the public. $^{101}$

The FDA's 1992 Policy Statement indicated that 'prudent' developers of foods using new technologies, including new plant varieties, would consult with the FDA before commercial distribution of foods or feed from new plant varieties. $^{102}$ In 1997, therefore, the FDA published a 'Guidance on Consultation Procedures' for industry, listing information (including safety and nutritional assessments) that should be submitted to the FDA and describing the procedure for consultation. ${ }^{103}$ The FDA recommended initial biotechnology consultations on new plant varieties prior to commercialisation, other consultations as necessary, and a final consultation once the developer has documentation - including detailed safety and nutritional assessments - to show that its new product is safe. FDA scientists review the data to identify unresolved scientific and regulatory issues. ${ }^{104}$ Biotechnology consultation is

99 FDA, Premarket Notice Concerning Bioengineered Foods, 66 Fed Reg 4706, 4711 (18 January 2001), to be codified at 21 CFR pts 192 and 592. Because consultation is successful and protects public health, the FDA indicated that the rule may not be needed: GAO, GE Crops, above n 22, 44.

${ }^{100}$ CFSAN, FDA, Guidance for Industry: Voluntary Labeling Indicating Whether Foods Have or Have Not Been Developed Using Bioengineering (Draft, Jan 2001) <http://www.fda.gov/Food/GuidanceComplianceRegulatoryInformation/GuidanceDocuments /FoodLabelingNutrition/ucm059098.htm> at 26 October 2009. ('FDA, Draft Guidance: Voluntary Labeling').

101 See Erica Seiguer and John J Smith, 'Perception and Process at the Food and Drug Administration: Obligations and Trade-Offs in Rules and Guidances’ (2005) 60 Food and Drug Law Journal 17, 20.

102 FDA, 1992 Policy, above n 62, 22,991.

103 CFSAN, FDA, Guidance on Consultation Procedures - Food Derived from New Plant Varieties (October 1997) <http://www.fda.gov/Food/GuidanceComplianceRegulatory Information/GuidanceDocuments/Biotechnology/ucm096126.htm> at 26 October 2009 ('FDA, 1997 Consultation').

${ }^{104}$ Ibid pt II. 
voluntary, but food companies do follow the practice, ${ }^{105}$ perhaps in part to avoid liability triggered by unsafe foods.

In 2006, the FDA issued another guidance document, which recommended early food safety evaluation of certain new GM food varieties. ${ }^{106}$ Recognising the likelihood of cross-pollination from field tests and commingling of seeds, the FDA addressed the possibility of 'inadvertent, intermittent, low-level presence in the food supply of proteins that have not been evaluated through the FDA's voluntary consultation process'. ${ }^{107}$ Questions about the safety of a new protein should be resolved before the developer carries out any activity that could result in the protein entering the food supply. The guidance document therefore encourages developers to submit food safety data about new proteins early (perhaps at the time of field tests), before those new proteins enter the food supply via pollen flow or commingling. ${ }^{108}$ Early food safety evaluation precedes the biotechnology consultation, which occurs when developers plan to commercialise new plant varieties. Developers can use data from the food safety evaluation in the later consultation. ${ }^{109}$

\section{E FDA Regulation}

\section{$1 \quad$ Food Additives}

The FDA governs GM food under its authority to regulate food additives. Under the FDCA, a food is adulterated if it bears or contains an added 'poisonous or deleterious substance which may render it injurious to health',

\footnotetext{
105 See Larry Thompson, ‘Are Bioengineered Foods Safe?' (2000) 34(1) FDA Consumer Magazine (Jan-Feb) 18.

106 CFSAN, FDA, Guidance for Industry: Recommendations for the Early Food Safety Evaluation of New Non-Pesticidal Proteins Produced by New Plant Varieties Intended for Food Use (June 2006) <http://www.fda.gov/Food/GuidanceComplianceRegulatory Information/GuidanceDocuments/Biotechnology/ucm096156.htm> at 26 October 2009 ('FDA, 2006 Guidance'). The GAO recommended that the EPA post results of these evaluations on its website and that, at an early stage, the FDA and USDA share information about GM crops that might raise health concerns or cause financial losses: GAO, GE Crops, above $n$ 22, 46.

${ }^{107}$ FDA, 2006 Guidance, above n 106, 3. In the 10 years prior to 2006, the FDA had reviewed over 60 bioengineered food products, which were deemed as safe as conventional counterparts. Robert E Brackett, 'Testimony on The Regulation of Dietary Supplements: A Review of Consumer Safeguards' (Committee on Government Reform, US House of Representatives, 9 March 2006) <www.hhs.gov/asl/testify/t060309.html> at 25 March 2009.

${ }^{108}$ FDA, 2006 Guidance, above n 106, 4-5. PIPs, of course, are regulated by the EPA.

${ }^{109}$ Ibid 6 (III.C.3.). For a recent practical application, see CFSAN, Office of Food Additive Safety, U.S. Food and Drug Administration's Statement on LLRICE 600 Series (March 2007) <http://www.fda.gov/Food/Biotechnology/Announcements/ucm109406.htm > at 26 October 2009.
} 
an unsafe pesticide residue, or an unsafe additive. ${ }^{110}$ A food additive is considered unsafe unless it has been granted premarket approval or is exempt from approval. ${ }^{111}$ To gain approval of a new food additive, the manufacturer submits a food additive petition, accompanied by studies to prove the safety of the additive. Approval requires that the FDA be convinced that the proposed use of the additive is safe, ${ }^{112}$ with 'a reasonable certainty ... that the substance is not harmful under the intended conditions of use' ${ }^{113}$ If the FDA finds the additive safe, it will issue a regulation to that effect; otherwise additives are considered unsafe and therefore the food is adulterated. ${ }^{114}$

Most non-pesticidal GM foods escape rigorous premarket review as food additives under the GRAS concept. ${ }^{115}$ The FDCA definition of food additive $^{116}$ excludes substances 'generally recognised as safe' (GRAS). ${ }^{117}$ Substances that are GRAS - including many ingredients from natural sources and some chemical additives - are not food additives and are therefore exempt from regulation as food additives. ${ }^{118}$ The determination that a substance is

11021 USC § 342(a) (2006) (defining adulterated food). Any substance that is not 'an inherent constituent of food or whose level in food has been increased by human intervention' is 'added' under 21 USC § 342(a)(1) (2006). FDA, 1992 Policy, above n 62, 22,989.

11121 USC § 348(a) (2006). The Food Additives Amendment, enacted in 1958, did not address foods from new plant varieties, which had been regulated under 21 USC § 342(a)(1) (2006).

11221 USC § 348(b),(c) (2006). See § 321(u): "The term "safe" ... has reference to the health of man or animal.'

11321 CFR § 170.3(i) (2009).

${ }^{114}$ Unapproved additives are considered adulterated under 21 USC § 342(a)(2)(C) (2006).

${ }^{115}$ On GRAS, see Fred H Degnan, 'The GRAS Concept: Ensuring Food Safety and Fostering Innovation' ('GRAS Concept') in Fred H Degnan, FDA's Creative Application of the Law: Not Merely a Collection of Words (2006) 15-35. Degnan referred to Congress' enactment of GRAS as 'a display of practical judgment': at 15. The FDA has applied different interpretations to the GRAS provisions, but most recently GRAS is considered, as in the earliest interpretation, 'as a tool capable of more flexibility, thus permitting realistic food safety decisions and fostering new technology and innovation': at 15.

${ }^{116}$ A food additive is defined as a substance that is 'not generally recognized, among experts qualified by scientific training and experience to evaluate its safety, as having been adequately shown through scientific procedures ... to be safe under the conditions of its intended use ... .' 21 USC § 321(s) (2006).

117 The regulatory definition of GRAS, 21 CFR $\S 170.30$ (2009), reads in part: '(a) General recognition of safety may be based only on the views of experts qualified by scientific training and experience to evaluate the safety of substances directly or indirectly added to food. ... General recognition of safety requires common knowledge about the substance throughout the scientific community knowledgeable about the safety of substances directly or indirectly added to food.'

${ }^{118}$ FDA, 1992 Policy, above n 62, 22,989. In 1958, the FDA published the GRAS list of substances in its regulations, with the current list in 21 CFR pts 182 and 184 and 186 (2009). Paulette M Gaynor et al, FDA's Approach to the GRAS Provision: A History of Process (2006) <http://www.fda.gov/Food/FoodIngredientsPackaging/GenerallyRecognizedasSafe GRAS/ucm094040.htm> at 26 October 2009. 
GRAS, however, requires 'the same quantity and quality of scientific evidence as is required to obtain approval of a food additive regulation for the ingredient'. 119

The FDA concluded in 1992 that most GM foods will be considered GRAS because most new plant foods had been accepted widely as safe. ${ }^{120}$ The use of the GRAS concept for foods produced through biotechnology lets the Agency 'take advantage of the dual purposes of the [Food Additives Amendment] ensuring safety and fostering innovation by relying on the use of sound scientific judgment based on good science'. ${ }^{121}$ A lawsuit challenged the FDA's 1992 policy and its determination that most GM foods will be GRAS. Holding that the FDA's presumption of GRAS status for GM foods was not arbitrary and capricious, the court noted that the GRAS determination must be based on technical evidence of safety, which is generally known and accepted in the scientific community. The court deferred to the FDA's evaluation of scientific data within its area of expertise. ${ }^{122}$

The FDCA does not require the FDA to be informed about the additions of substances that manufacturers consider to be GRAS. ${ }^{123}$ The FDA uses a notification procedure outlined in a 1997 regulatory proposal, which has not yet been promulgated. ${ }^{124}$ Under that procedure, any person can notify the FDA of a claim that a particular use of a substance is exempt from premarket approval as GRAS. The FDA responds to GRAS notices, but an FDA response does not constitute approval. ${ }^{125}$ This means that companies themselves must decide whether a new food substance is GRAS or whether it is a food additive that requires FDA approval.

\footnotetext{
${ }^{119} 21$ CFR § 170.30(b) (2009). See Degnan, 'GRAS Concept', above n 115, $26-8$ (reviewing litigation on the standard for GRAS determination).

${ }^{120}$ FDA, 1992 Policy, above n 62, 22,990. The agency did not expect 'any serious question about the GRAS status of transferred genetic material', unless the substance (for example, protein, carbohydrate, fat, oil) differed 'significantly in structure, function, or composition from substances found currently in food'.

${ }^{121}$ Degnan, 'GRAS Concept', above n 115, 30.

${ }^{122}$ Alliance for Bio-Integrity v Shalala, 116 F Supp 2d 166, 177 (D DC 2000), citing 21 CFR § 170.30(a), (b).

${ }^{123}$ See 21 USC § 348 (2006) and McGarity, above n 97, 455. A 1972 regulation (not yet repealed) allowed manufacturers to petition the FDA for affirmation of the GRAS status of new substances: 21 CFR § 170.35 (2009).

${ }^{124}$ FDA, Substances Generally Recognized as Safe, 62 Fed Reg 18,938 (17 April 1997).

125 See FDA, Guidance for Industry: Frequently Asked Questions about GRAS (2004) Q 15 $<$ http://www.fda.gov/Food/GuidanceComplianceRegulatoryInformation/GuidanceDocuments /FoodIngredientsandPackaging/ucm061846.htm> at 26 October 2009. Between 1997 and February 2006, 193 GRAS Notices had been filed. Gaynor et al, above n 118.
} 


\section{$2 \quad$ Labelling}

The FDA does not require labels for most GM foods. ${ }^{126}$ The FDCA defines a food as 'misbranded' if 'its labeling is false or misleading in any particular' ${ }^{127} \mathrm{~A}$ factor in determining whether a label is misleading is 'the extent to which the labeling ... fails to reveal [material] facts .... ${ }^{128}$ The FDA has interpreted the term 'material' to refer to attributes of the food product and has required special labels only when the absence of information could pose health or environmental risks, mislead the consumer, or allow the consumer to believe, wrongly, that one food has nutritional, functional, or other characteristics similar to another food. ${ }^{129}$

The FDA did not consider the methods used to develop new plant varieties to be material information under the FDCA, and the development of GM foods did not change the Agency's opinion. ${ }^{130}$ Moreover, the FDA was

not aware of any information showing that foods derived by these new methods differ from other foods in any meaningful or uniform way, or that, as a class, foods developed by the new techniques present any different or greater safety concern than foods developed by traditional plant breeding. ${ }^{131}$

Therefore, GM products need not be identified as GM unless the food itself differs significantly from similar foods - for example, in its nutritional content or the presence of an allergen. ${ }^{132}$ In a case that challenged the FDA's interpretation of 'material', the court upheld the FDA's determination that genetic modification is not a material fact that requires labelling. ${ }^{133}$

\footnotetext{
${ }^{126}$ FDA, 1992 Policy, above n 62, 22,991.

${ }^{127} 21$ USC § 343(a) (2006).

${ }^{128} 21$ USC § 321(n) (2006).

${ }^{129}$ Brackett, above n 107, 5. So, for example, if a tomato had an inserted peanut protein that might cause an allergic reaction, the presence of that protein would be a 'material fact', and its omission would make the label misleading. See 21 USC § 343(a),(w) (2006); FDA, 1992 Policy, above n 62, 22,991.

${ }^{130}$ FDA, 1992 Policy, above n 62, 22,991. The FDA believes that it has 'neither a scientific nor a legal basis to require such labeling': Brackett, above n 107, 5 .

${ }^{131}$ FDA, 1992 Policy, above n 62, 22,991.

${ }^{132}$ See Brackett, above n 107, 5. For example, a GM soybean variety had altered levels of oleic acid, resulting in soybean oil that differed from conventional soybean oil. The FDA advised that the oil be given a new name that reflected the difference.

${ }^{133}$ Alliance for Bio-Integrity $v$ Shalala, 116 F Supp 2d 166, 179 (D DC 2000). Because the FDA had determined that genetic modification does not alter foods materially, a determination to which the court granted deference, it lacked a legal basis for requiring labels, even in the face of consumer demand. See generally Fred H Degnan, 'Biotechnology and the Food Label' in Paul Weirich (ed), Labeling Genetically Modified Food: The Philosophical and Legal Debate (2007) 17-31.
} 
Because consumers may be interested in whether food has been genetically modified, however, the FDA published a Draft Guidance to help industry ensure that voluntary labelling is truthful and does not mislead consumers. The document gives examples of statements that could be used on food labels without causing the label to be misleading and the food therefore misbranded. ${ }^{134}$

\section{EuRopean Community Regulation of GM Crops}

A number of genetically modified organisms ${ }^{135}$ and their food and feed products have been approved for consumption or processing in the European Union. About 27 varieties are approved for food, feed, and other purposes. GMOs approved for consumption are listed in the Community Register of Genetically Modified Food and Feed. ${ }^{136}$ Only GM maize is approved for cultivation, ${ }^{137}$ however, and since 1998 no new product has been approved for cultivation, though a number await approval. New crop varieties may not be sold and planted in Member States until they are listed in the EU Common Catalogue of Varieties of Agricultural Plant Species. ${ }^{138}$ The Commission added 17 varieties of corn, derived from Monsanto's MON810 maize and authorised in 1998, to the list in 2004. ${ }^{139}$ Only varieties derived from MON810 and Syngenta's Bt176 were cultivated commercially in the European Union, but, in April 2007, the Commission withdrew Bt176 and its

\footnotetext{
${ }^{134}$ FDA, Draft Guidance: Voluntary Labeling, above n 100, 3 and 4-6. The Guidance, which reaffirmed the FDA's decision not to require labels for all GM food, remains in draft form.

${ }^{135}$ For more detail on EC regulatory measures see Margaret Rosso Grossman, 'Traceability and Labeling of Genetically Modified Crops, Food, and Feed in the European Union’ (2005) 1 Journal of Food Law and Policy 43, 53-71.

${ }^{136}$ See DG Health and Consumer Protection, European Commission, Community Register of Genetically Modified Food and Feed <http://ec.europa.eu/food/dyna/gm_register/index_ en.cfm> at 13 November 2009 (listing 27 authorised varieties of cotton, maize, microorganisms, oilseed rape, soybeans, and sugar beet).

137 For current information, see GMO Compass, GMO Database <http://www.gmocompass.org/eng/gmo/db/> at 26 March 2009. Many of the GM corn events approved in the US are not approved in the EU.

138 The Common Catalogue is governed by Council Directive (EC) 2002/53 [2002] OJ L193/1, as amended. See Common Catalogue of Varieties of Agricultural Plant Species (2008) $<$ http://ec.europa.eu/food/plant/propagation/catalogues/comcat_agri_2008/index_en.htm> at 27 March 2009.

${ }^{139}$ European Commission, 'Inscription of MON 810 GM maize varieties in the Common EU Catalogue of Varieties' (Press Release IP/04/1083, 8 September 2004).
} 
products from the market. ${ }^{140}$ Moreover, MON810 has engendered controversy and several Member States have banned its cultivation.

A complex and interrelated system of Directives and Regulations, designed to ensure that authorised GMOs do not threaten health or the environment, governs GMOs and their food and feed products. In 1990, the European Community introduced a process-based regulatory system that requires caseby-case authorisation of GMOs and follows a step-by-step process of decreasing containment. Later amendments and new measures strengthened the regulatory system, adding requirements for traceability and labelling, with thresholds for applicability to ensure that producers and consumers enjoy freedom of choice between GM and other crops. Nonetheless, the process of authorisation, interrupted by a lengthy (1998-2004) moratorium, has moved slowly, and suspicion about GM crops and their products remains.

EC Directives govern the contained use of genetically modified microorganisms $^{141}$ and the deliberate release of GMOs. ${ }^{142}$ EC Regulations govern GM food and feed ${ }^{143}$ and the traceability and labelling of GMOs and food and feed products produced from GMOs. ${ }^{144}$ In addition to measures that govern

\footnotetext{
${ }^{140}$ Syngenta had stopped selling seeds after 2005 and did not plan to seek renewal of its authorisation. Commission Decision (EC) 2007/304 on the Withdrawal from the Market of Bt176 (SYN-EV176-9) Maize and its Derived Products [2007] OJ L117/4. Adventitious or technically unavoidable presence of Bt176, in a proportion no higher than 0.9 percent, will be tolerated for five years.

${ }^{141}$ Council Directive 90/219 on the Contained Use of Genetically Modified Micro-organisms [1990] OJ L 117/1, as amended, now recast as Parliament and Council Directive 2009/41 on the Contained Use of Genetically Modified Micro-organisms [2009] OJ L 125/75. The first Directive on deliberate release was Council Directive 90/220 [1990] OJ L 117/15 (repealed in 2002).

${ }^{142}$ Parliament and Council Directive 2001/18 on the Deliberate Release into the Environment of Genetically Modified Organisms and Repealing Council Directive 90/220 [2001] OJ L 106/1, as amended. Consolidated text: CONSLEG 2001L0018-21.03.2008.

${ }^{143}$ Parliament and Council Regulation 1829/2003 on Genetically Modified Food and Fee [2003] OJ L 268/1, as amended. Consolidated text: CONSLEG 2003R1829-10.04.2008.

${ }^{144}$ Parliament and Council Regulation 1830/2003 Concerning the Traceability and Labelling of Genetically Modified Organisms and the Traceability of Food and Feed Products Produced from Genetically Modified Organisms and Amending Directive 2001/18 [2003] OJ L 268/24, as amended. CONSLEG 2003R1830-11.12.2008. Article 43 amends Directive 2001/18.

The last two Regulations replace several earlier measures, including Council Regulation 1139/98 [1998] OJ L 159/4 (labelling of food produced from GMOs); Commission Regulation 49/2000 [2000] OJ L 6/13 (amending Regulation 1139/98); Commission Regulation 50/2000 [2000] OJ L 6/15 (labelling for GM additives and flavourings). They also replace the Novel Foods Regulation, Parliament and Council Regulation 258/97 [1997] OJ L 43/1, which had governed pre-market authorisation and labelling for GM foods, insofar as it applied to GMOs, but parts of that Regulation remain in effect.
} 
GMOs and their products, the General Food Law ${ }^{145}$ sets out general principles and establishes the European Food Safety Authority (EFSA), which plays an important role in authorising GM food and feed.

\section{A Contained Use and Deliberate Release}

Directive 2009/41, enacted in 2009 to replace Directive 90/219, governs the contained use of genetically modified micro-organisms (GMMs). 'Contained use' involves activities in which micro-organisms are genetically modified or in which GMMs are used and for which 'specific containment measures' protect the general public and the environment. ${ }^{146}$ The Directive thus governs research, laboratory, and industrial work with GMMs. Member States implement the Directive through designated competent authorities that inspect and carry out other control measures. Users determine the level of risk and the containment level required to avoid adverse effects on health and environment. ${ }^{147}$ Users must apply the appropriate containment and other protective measures and notify Member State authorities of activities conducted on their premises. ${ }^{148}$ Member States inform the Commission annually about their activities, with a summary every three years, and report relevant incidents (for example, accidents) to the Commission and other Member States. ${ }^{149}$

After a decade of experience with an earlier Directive, ${ }^{150}$ the European Community enacted Directive 2001/18 on deliberate release of GMOs, designed to make the authorisation of GMOs more efficient and transparent and to control possible risks to human health and the environment. ${ }^{151}$ This Directive imposed more stringent measures for environmental risk assessment, required post-market monitoring, limited authorisation of GMOs to 10 years, and required Member States to ensure traceability and labelling of

\footnotetext{
${ }^{145}$ Parliament and Council Regulation 178/2002 of 28 January 2002 Laying Down the General Principles and Requirements of Food Law, Establishing the European Food Safety Authority and Laying Down Procedures in Matters of Food Safety [2002] OJ L 31/1, as amended. Consolidated text: CONSLEG 2002R0178-25.03.2008.

${ }^{146}$ Directive 2009/41, art 2(c).

${ }^{147}$ Directive 2009/41, arts 4 and 5. Moderate or high risk contained use of GMMs requires prior written consent of the competent authority: art 9.

${ }^{148}$ Directive 2009/41, arts 6-11.

149 Annexes to Directive 2009/41 describe techniques of genetic modification (Annex I); excluded techniques and safety criteria (Annex II); principles to be applied in the risk assessment (Annex III); measures required for various types of containment - laboratories, growing rooms, animal units, other activities (Annex IV); and information required for notifications required by the Directive (Annex V).

${ }^{150}$ Council Directive 90/220 [1990] OJ L 117/15, as amended (repealed 2002).

${ }^{151}$ Directive 2001/18, preamble (5), (48) [2001] OJ L 106/1, 3.
} 
GMOs at all stages. ${ }^{152}$ A number of other regulatory measures supplement Directive 2001/18. ${ }^{153}$

Directive 2001/18 defines a GMO as 'an organism, with the exception of human beings, in which the genetic material has been altered in a way that does not occur naturally by mating and/or natural recombination'. ${ }^{154}$ General provisions - for example, confidentiality and consultation requirements apply to all GMOs. ${ }^{155}$ Moreover, anyone who plans to seek authorisation to release a GMO must carry out an environmental risk assessment, which evaluates potential adverse effects of the release on human health and the environment using principles for risk assessment set out in the Directive. ${ }^{156}$

Directive 2001/18 implements a step-by-step principle:

[t]he containment of GMOs is reduced and the scale of release increased gradually, step by step, but only if evaluation of the earlier steps in terms of protection of human health and the environment indicates that the next step can be taken. ${ }^{157}$

The Directive therefore governs the deliberate release of GMOs in two steps: first for 'any other purpose than for placing on the market' (for example, field tests) and then for 'placing on the market of GMOs as or in products' (that is, the sale of GMOs or their products). ${ }^{158}$

Deliberate release at the research stage is one of the steps preliminary to marketing, because GMOs must be field tested in appropriate ecosystems. Member States, through their competent authorities, authorise releases for field testing or other research under the procedure and time frames specified

\footnotetext{
152 Member States were to have implemented Directive 2001/18 in their national laws by 17 October 2002. Directive 2001/18, art 34. Not all States did so, however. See Commission v French Republic (C-121/07), linked from <http://curia.europa.eu> at 16 April 2009 (fining France EUR 10 million for failure to implement the Directive).

153 These include detailed guidance notes (for example, Council Decision 2002/811 [2002] OJ L 280/27; Commission Decision 2002/263 [2002] OJ L 200/22), format instructions for submitting information (for example, Council Decision 2002/812 [2002] OJ L 280/37; Council Decision 2002/813 [2002] OJ L 280/62; Commission Decision 2003/701 [2003] OJ L 254/21), and arrangements for GMO registers (for example, Commission Decision 2004/204 [2004] OJ L 65/20).

${ }^{154}$ Directive 2001/18, art 2(2), 2001 OJ L 106.

${ }^{155}$ Directive 2001/18, art 3.

${ }^{156}$ Directive 2001/18, art 6; Annex III. The Directive identifies the types of information that might be needed to carry out the risk assessment for higher plants and other organisms. Annex II, 19-22.

${ }^{157}$ Directive 2001/18, preamble (24).

${ }^{158}$ Directive 2001/18, pt B and pt C.
} 
in the Directive. ${ }^{159}$ No release is permitted without written consent from the competent authority. After the release, the notifier reports results, especially concerning risk to health or the environment, to the competent authority. ${ }^{160}$

Member States must establish registers to record the location of releases for field tests and for releases of GMOs that have been approved and placed on the market. ${ }^{161}$ Registration of the use of approved GMOs is intended, in part, to facilitate monitoring of their effect on the environment. The locations of releases and environmental risk assessments are to be made known to the public. ${ }^{162}$ In February 2009, the European Court of Justice held that the public may request all information relating to the locations of releases submitted to the competent authority in the Member State. It also held that such information may not be withheld under an exception to disclosure relating to protection of the public order. ${ }^{163}$

\section{B Placing GMOs on the Market}

An authorised GMO may be used 'without further notification throughout the community', and Member States may not 'prohibit, restrict or impede the placing on the market of [authorised] GMOs, as or in products'. ${ }^{164}$ Therefore the process of placing GMOs and their products on the market is more complicated than authorisation of experimental releases and involves the Commission, EFSA, and the competent authorities of all Member States. ${ }^{165}$ Directive 2001/18 governs the placement of GMOs on the market, and Regulation 1829/2003 governs GM food and feed. The process of authorisation helps to ensure that GMOs or their products do not pose risks to health or the environment.

\footnotetext{
159 These steps include notification to the Member State competent authority, with a detailed technical dossier and environmental risk assessment: Directive 2001/18, art 6 and Annex III. The Commission receives a summary of each notification and forwards it to other Member States: at art 11. If appropriate, Member States may consult the public: at art 9(1).

${ }^{160}$ Directive 2001/18, art 10. Member States must make available to the public information on all releases in their territory, but without disclosing confidential information: at arts 9(2) and 25.

${ }^{161}$ Directive 2001/18, art 31(3)(a), (b).

162 Directive 2001/18, art 31(3)(b). Decision 2004/204 [2004] OJ L 65/20, sets forth detailed guidance for publicly accessible registers in Member States. To protect commercial interests, two sets of data should be maintained, one accessible to the public and the other accessible only to Member States, the Commission, and the European Food Safety Authority (EFSA).

163 Commune de Sausheim v Azelvandre, C-552/07 linked from <http://curia.europa.eu> at 19 February 2009.

${ }^{164}$ Directive 2001/18, art 19(1); art 22 (without prejudice to the safeguard clause in art 23).

165 Moreover, products containing or consisting of GMOs cannot be imported into the EC if they do not comply with EC requirements: Directive 2001/18 preamble (11).
} 


\section{GMOs - Directive 2001/18}

Authorisation begins with notification to the Member State competent authority, with information about the GMO, an environmental risk assessment, a plan for post-release monitoring, ${ }^{166}$ conditions for use and handling of the product, a summary of the dossier, and other information. ${ }^{167}$ If, after examining the notification for compliance with the Directive and preparing an assessment report, the Member State authority concludes that the GMO should be placed on the market, the authority sends the dossier summary, along with its assessment report, to the Commission and to the competent authorities of the other Member States. ${ }^{168}$ States may ask for information, make comments, or present 'reasoned objections' ${ }^{169}$ If no objections are made, or if issues are resolved, the competent authority may give written consent to the notifier. ${ }^{170}$ Written consent must include specific conditions for use, handling and packaging of the GMO or for protection of the environment, labelling requirements, and obligations for monitoring. ${ }^{171}$ Written consent is given for a maximum of 10 years and can be renewed. ${ }^{172}$

If the Commission or a Member State raises and maintains an objection to consent - the situation for most GMOs so far - the Commission must consult the competent Scientific Committee, EFSA's Scientific Panel on GMOs. ${ }^{173}$ If the scientific decision is favourable, the Commission will follow the Community inter-agency regulatory procedure, the so-called comitology procedure, to reach a decision. Commission consent has authorised GMOs under a comitology procedure since 2004, but a 2006 amendment adds a

\footnotetext{
${ }^{166}$ Directive 2001/18, Annex VI; Decision 2002/811, Annex [2002] OJ L 280/27. The postrelease monitoring plan is important to ensure that assumptions underlying the environmental risk assessment were correct and to identify unanticipated adverse effects on human health or the environment.

${ }^{167}$ Directive 2001/18, art 13.

${ }^{168}$ Directive 2001/18, art 14. The Commission makes information available to the public: art 24(1). If the competent authority rejects the notification, the procedure differs slightly: art 14 .

${ }^{169}$ Directive 2001/18, art 15(1).

${ }^{170}$ Directive 2001/18, art 15(3). In a case brought under Directive 90/220, the European Court of Justice held that when no objections are raised, the competent authority is obliged to give consent: Ass'n Greenpeace France v Ministère de l'Agriculture et de la Pêche (C-6/99) [2000] ECR I-6031.

${ }^{171}$ Directive 2001/18, art 19(3) [2001] OJ L 106/12. After consent, notifiers must follow the prescribed monitoring plan and report regularly to the Commission and competent authorities; results of monitoring are also available to the public: art 20.

${ }^{172}$ Directive 2001/18, arts 15(4) and 17.

${ }^{173}$ Directive 2001/18, art 28.
} 
'regulatory procedure with scrutiny'. ${ }^{174}$ Under this more complicated procedure, which applies to GMOs, either Council or Parliament can block adoption of a draft measure. ${ }^{175}$

Even after consent is granted, a safeguard clause protects Member States. This clause allows a Member State provisionally to restrict or prohibit use or sale of a GMO or a GM product in its territory if the State has new information to demonstrate that the GMO poses a risk to human health or the environment. ${ }^{176}$ The Member State informs the Commission and other Member States; the Commission, with assistance of the Scientific Committee, decides whether the Member State's action is justified. A number of Member States have invoked the safeguard clause in attempts to ban GMOs in their territories. ${ }^{177}$ Most recently, in April 2009, the German agriculture minister banned sale and cultivation of MON810 maize. ${ }^{178}$ Member States have not been forced to overturn their bans. In March 2009, for example, the Council rejected Commission proposals to lift national safeguards in Hungary and Austria. ${ }^{179}$

Article 95(5) of the EC Treaty offers an additional safeguard. After adoption of a Council or Commission harmonisation measure, Member States may

${ }^{174}$ Directive 2001/18, arts 18 and 30(2). The comitology procedure is set out in Council Decision 1999/468, art 5 [1999] OJ L 184/23, as amended by Council Decision 2006/512 [2006] OJ L 200/11.

175 The Commission submits a draft of the measure to be taken (that is, a legislative decision to give consent to placing the GMO on the market) to a regulatory committee made up of Member State representatives. If the regulatory committee agrees, the Commission submits the draft measure to the European Parliament and Council for scrutiny. If neither body opposes the draft measures, the Commission adopts the measure, but if either body opposes the draft, the Commission may not adopt the measure. If the regulatory committee disagrees or gives no opinion on the Commission draft, the Commission submits the draft to the Council. If the Council opposes the measure, it will not be adopted. If the Council wants to adopt the measure, it is submitted to the Parliament, which may oppose (and thereby block) the measure. Council Decision 1999/468, art 5a, added by Council Decision 2006/512 [2006] OJ L 200/11.

${ }^{176}$ Directive 2001/18, art 23. The State's belief must be based on information made available since the date of consent or on a reassessment of existing information using new scientific information.

177 Six Member States invoked the safeguard clause (Directive 90/220, art 16) in 9 applications. In each instance, no justification for the State ban was found, but the Council has not acted to lift the bans. Commission, Questions and Answers on the Regulation of GMOs in the European Union (Memo/07/117, 26 March 2007) 6-7.

178 BBC News, 'Germany Bans Monsanto's GM Maize' (14 April 2009) $<$ http://news.bbc.co.uk/2/hi/7998181.stm> at 14 October 2009. Monsanto sued, but in early May 2009, a German court denied an injunction against the ban. Verwaltungsgericht Braunschweig, 'Genmais bleibt verboten' (Press Release, 5 May 2009) <http://www.verwaltungsgericht-braunschweig.niedersachsen.de> at 12 May 2009.

179 Council, '2928th Council Meeting: Environment, Brussels' (Press Release 7042/09, 2 March 2009) 8-9. 
introduce national provisions 'based on new scientific evidence relating to the protection of the environment ... on grounds of a problem specific to that Member State arising after the adoption of the harmonisation measure'. ${ }^{180}$ The Commission must determine whether the Member State provisions discriminate or restrict trade and whether they interfere with the internal market. ${ }^{181}$ Relying on this Treaty provision, Austria proposed to ban cultivation of approved GMOs in Upper Austria, justifying its measure as a means to protect traditional and organic production systems, nature, the environment and biodiversity. Its proposed ban was rejected, both by the Commission and in subsequent litigation. ${ }^{182}$

\section{Food and Feed - Regulation 1829/2003}

To protect the health of humans and animals, Regulation 1829/2003 governs GM food and feed. ${ }^{183}$ Relying on principles articulated in Directive 2001/18, it uses the framework for risk assessment set out in the General Food Law. EFSA administers Regulation 1829/2003 and, with assistance from Member State agencies, assesses the risks of GM food or feed. ${ }^{184}$ The Scientific Panel on GMOs plays a major role. ${ }^{185}$ Under the 'one door-one key' principle, a single application may cover a GMO and food or feed containing or consisting of that GMO. ${ }^{186}$ Separate, but similar, measures govern GM food

\footnotetext{
${ }^{180}$ Treaty Establishing the European Community, art 95(5) [2002] OJ C 325/33 (consolidated version) ('EC Treaty'). Article 95(4) includes an analogous provision for existing Member State measures.

${ }^{181}$ EC Treaty, art 95(5), (6).

${ }^{182}$ To evaluate the scientific justification for the proposed Austrian ban, the Commission asked the advice of EFSA, which consulted the Scientific Panel on Genetically Modified Organisms. EFSA concluded that Austria's justification did not meet the requirements of $E C$ Treaty art 95(5), because Austria did not provide new scientific evidence related to protection of the environment, prove that its concerns about the coexistence of organic and GM crops were environmental, or show that Upper Austria had unique ecosystems. The Commission therefore rejected Austria's proposed national provisions. Commission Decision 2003/653 [2003] OJ L 230/34, 36. Litigation followed. The Court of First Instance found the bans illegal. Land Oberösterreich v Commission (T-366/03 and T-234/04) [2005] ECR II-4005. In September 2007, the European Court of Justice agreed that the bans were illegal. Joined Cases, Land Oberösterreich v Commission (C-439/05 P \& C-454/05 P) [2007] ECR I-7141.

${ }^{183}$ Regulation 1829/2003, art 1 [2003] OJ L 268/1. See also Commission, Report on the implementation of Regulation (EC) No. 1829/2003, COM (2006) 626 final (25 October 2006).

${ }^{184}$ Regulation 1829/2003, art 6.

${ }^{185}$ Regulation 178/2002, art 28(1), (4)(d), [2002] OJ L 31/1. The Scientific Committee and permanent Scientific Panels of independent scientific experts are responsible for providing EFSA's scientific opinions: art 28(1).

${ }^{186}$ Regulation 1829/2003, arts 5(5), 17(5).
} 
and feed, and products likely to be used as both food and feed may be authorised under a single application. ${ }^{187}$

Regulation 1829/2003 governs GMOs for food use, food containing or consisting of GMOs, and food produced from or containing ingredients produced from GMOs. ${ }^{188}$ Its requirements apply in a 'non-discriminatory manner' to both Community and imported products. ${ }^{189}$ Products that are produced with a GMO but have no GM material in the end product (for example, food made with GM processing or products from animals fed with GM feed) are excluded from regulation. ${ }^{190}$ GMOs to be used as seeds are governed by other measures. ${ }^{191}$

GM food authorised under Regulation 1829/2003 must have no adverse effects on health or the environment, and it must not mislead the consumer or differ in a nutritionally adverse way from the food it replaces. ${ }^{192}$ Authorisation involves a scientific evaluation followed by a risk management decision. ${ }^{193}$ EFSA prepares its opinion on the basis of scientific analysis and consultation with experts and, for GMOs under the one door-one key procedure, with Member State competent authorities. After notice and comment, the Commission submits a draft decision on the authorisation to the Standing Committee on the Food Chain and Animal Health. ${ }^{194}$ The inter-agency regulatory procedure, mentioned above, is used to reach final decision on the application. ${ }^{195}$ Authorisation of GM food is valid throughout the Community

\footnotetext{
187 Regulation 1829/2003, art 27. This article focuses on authorisation of GM food. See also EFSA, Guidance Document of the Scientific Panel on Genetically Modified Organisms for the Risk Assessment of Genetically Modified Plants and Derived Food and Feed (2006) EFSA Journal 99, 1-100 (providing guidance for the preparation and presentation of applications within the framework of Regulation 1829/2003). For information about the 2008 draft update, see <http://www.efsa.europa.eu/EFSA/efsa_locale-1178620753812_1211902599947.htm> at 26 October 2009

${ }^{188}$ Regulation 1829/2003, art 3(1). 'Produced from GMOs' means 'derived, in whole or in part, from GMOs, but not containing or consisting of GMOs’: art 2(10).

189 Regulation 1829/2003, preamble (43). The Regulation takes account of commitments to international trade and obligations under the Cartagena Protocol: art 44.

${ }^{190}$ Regulation 1829/2003, preamble (16).

191 Regulation 1829/2003, preamble (34) and art 6(3)(c).

192 Regulation 1829/2003, art 4(1).

193 Regulation 1829/2003, preamble (9). In consultation with EFSA, the Commission has enacted detailed rules to guide the preparation of applications. See Commission Regulation 641/2004 [2004] OJ L 102/14.

${ }^{194}$ Regulation 1829/2003, arts 7(1) and 35(1).

195 See Regulation 1829/2003, arts 7(3) and 35(2), as amended (referencing Council Decision 1999/468 [1999] OJ L 184/23). See also Regulation 298/2008 [2008] OJ L 97/64 (amending Regulation 1829/2003 to incorporate the regulatory procedure with scrutiny).
} 
for ten years and can be renewed. ${ }^{196}$ The Community Register of Genetically Modified Food and Feed lists authorised GM foods. ${ }^{197}$

\section{Traceability and Labelling}

Both traceability and labelling are important food safety measures for the European Union, and Regulations enacted in 2003 harmonise these requirements.

\section{Traceability}

The 2002 General Food Law requires that business operators implement systems and procedures (including labelling) to ensure traceability of food, feed, and food-producing animals. ${ }^{198}$ For GMOs specifically, Directive 2001/18 emphasises the importance of traceability ${ }^{199}$ and requires labelling. Consent to place a GMO on the market is contingent on compliance with labelling requirements, including a statement that 'this product contains genetically modified organisms'.200

Regulation 1830/2003 is more specific. Building on Directive 2001/18, it defines traceability as 'the ability to trace GMOs and products produced from GMOs at all stages of their placing on the market through the production and distribution chains'. ${ }^{201}$ Traceability is essential to ensure proper labelling, monitor environmental and health effects, implement risk management measures, and, if necessary, to withdraw food products from the market. ${ }^{202}$ The Regulation applies a unified system of traceability to products consisting of or containing GMOs, as well as food and feed produced from GMOs. ${ }^{203}$

\footnotetext{
${ }^{196}$ Regulation 1829/2003, arts 7(5) and 11.

${ }^{197}$ Regulation 1829/2003, arts 7(5) and 28. The Register is cited above n 136.

${ }^{198}$ Regulation 178/2002, art 18 [2002] OJ L 31/1. The General Food Law defines 'traceability' as 'the ability to trace and follow a food, feed, food-producing animal or substance intended to be, or expected to be incorporated into a food or feed, through all stages of production, processing and distribution': art 3(15).

199 'It is necessary to ensure traceability at all stages of the placing on the market of GMOs as or in products authorised under [the placing on the market provisions] of this Directive': Directive 2001/18, preamble (42) [2001] OJ L 106/1.

${ }^{200}$ Directive 2001/18, arts 13(2)(f), 19(3)(e), Annex IV.

${ }^{201}$ Regulation 1830/2003, art 3(3) [2003] OJ L 268/24. This definition differs slightly from the definition in the General Food Law, quoted above n 198. See Commission, Report on the Implementation of Regulation (EC) No 1830/2003, COM (2008) 560 final (17 September 2008) (reporting on implementation of the Regulation in the Member States).

${ }^{202}$ Regulation 1830/2003, art 1.

${ }^{203}$ Regulation 1830/2003, art 2(1).
} 
If products consist of or contain GMOs, operators (those who place a product on the market or receive a product placed on the market) ${ }^{204}$ must transmit prescribed information in writing at the first and all subsequent stages of placing on the market. Two types of information are prescribed: a statement that the product contains or consists of GMOs and the unique identifier(s) assigned to the GMOs. Operators must preserve this information and the identity of those from whom the products were received and to whom they were made available for five years from each transaction. Pre-packaged products must have a statement on a label (for example, 'This product contains genetically modified organisms'), and a display of bulk products offered to the final consumer must include similar language. ${ }^{205}$ For food and feed produced from GMOs, the operator must indicate in writing each food ingredient produced from GMOs. If no list of ingredients exists, the operator must indicate that the product is produced from GMOs. The same five-year retention period applies. ${ }^{206}$

Implementation of Regulation 1830/2003 requires a system of unique identifiers for GMOs, established by the Commission. ${ }^{207}$ All GMOs placed on the market are to have a unique identifier, specified in the consent for that GMO. ${ }^{208}$ The applicant for a new GMO develops the unique identifier, ${ }^{209}$ and the Commission has established a central register with information about GMOs authorised in the European Union. ${ }^{210}$

\section{$2 \quad$ Labelling}

Regulation 1830/2003 requires labels for products consisting of or containing GMOs. Operators must use the phrase 'This product contains genetically modified organisms' or 'This product contains genetically modified [name of

\footnotetext{
${ }^{204}$ Regulation 1830/2003, art 3(5)

${ }^{205}$ Regulation 1830/2003, art 4(1), (4), (6).

${ }^{206}$ Regulation 1830/2003, art 5.

${ }^{207}$ See Commission Regulation (EC) No 65/2004 of 14 January 2004 Establishing a System for the Development and Assignment of Unique Identifiers for Genetically Modified Organisms [2004] OJ L 10/5.

208 The unique identifier is to be registered with the Commission and with the Biosafety Clearing-House (<http://bch.biodiv.org/>) established in connection with the Cartagena Protocol: Regulation 65/2004 arts 2-3. Identifiers will be coordinated with the Organisation for Economic Co-operation and Development (OECD), BioTrack Product Database $<$ http://www2.oecd.org/biotech/> at 27 March 2009.

${ }^{209}$ Each identifier has nine alphanumeric digits, divided into three components separated by hyphens. The components identify the applicant or consent holder and the transformation event, and the final digit is a verification number: Regulation 65/2004, Annex.

${ }^{210}$ See Decision 2004/204 [2004] OJ L 65/20 (enacted under article 31(2) of Directive 2001/18).
} 
the organism(s)]'. ${ }^{211}$ Regulation 1829/2003 has similar labelling requirements for GM food and feed that contains or consists of GMOs or is produced from or contains ingredients produced from GMOs. The Regulation provides detail about the language required to indicate genetically modified content. In addition, labels must identify food that may raise ethical or religious concerns and food that is different from its conventional counterpart in composition, nutritional value or effects, intended use, or health implications. ${ }^{212}$ Regulation $1829 / 2003$ does not require labelling of products produced with GMOs or products from animals fed with GM feed.

\section{Thresholds}

Some products that contain 'adventitious or technically unavoidable' traces of authorised GMOs may not have to be labelled, and some traceability requirements will not apply to those products. ${ }^{213}$ Regulation 1830/2003 states that 'traces of GMOs in products' do not trigger traceability and labelling requirements if the traces do not exceed the threshold set in Directive 2001/18. ${ }^{214}$ For products intended for direct processing, Directive 2001/18 indicates that labelling is not required for adventitious or technically unavoidable traces of authorised GMOs of no more than 0.9 per cent, but lower thresholds can be established. ${ }^{215}$ For products intended for direct food or feed use or for processing, Regulation 1829/2003 prescribes the threshold: 0.9 per cent of food ingredients considered individually or food consisting of a single ingredient. ${ }^{216}$ The European Community has not yet established a threshold for traces of authorised GM seeds, as permitted by Directive $2001 / 18^{217}$

\footnotetext{
${ }^{211}$ Regulation 1830/2003, art 4(6) [2003] OJ L 268/24, 26. For pre-packaged products, the words must appear on the label; for non-pre-packaged products, on or in connection with the product display. Specific labelling requirements in other EC legislations continue to apply.

${ }^{212}$ Regulation 1829/2003, arts 12-14 [2003] OJ L 268/1, 11-12, as amended. Labelling rules for feed, in art 25, are similar, though not identical.

${ }^{213}$ To prove that the presence of GM material is adventitious or technically avoidable, operators must be able to show that they have taken appropriate steps to avoid the presence of GM material: Regulation 1829/2003, art 12(3).

${ }^{214}$ Regulation 1830/2003, art 4(7).

215 See Directive 2001/18, art 21(3) (amended by Regulation 1830/2003, art 7). Threshold setting follows the regulatory process with scrutiny, described above in $\mathrm{n} 175$.

${ }^{216}$ Regulation 1829/2003, art 12(2). After crops lose authorisation, the 0.9 percent adventitious presence threshold applies for five years. See Commission Decision (EC) 2007/304 on the Withdrawal from the Market of Bt176 (SYN-EV176-9) Maize and its Derived Products [2007] OJ L117/4.

217 Directive 2001/18, art 21(2) (referring to 'products where adventitious or technically unavoidable traces of authorized GMOs cannot be excluded'). See Draft Commission Decision Establishing Minimum Thresholds for Adventitious or Technically Unavoidable
} 


\section{$4 \quad$ Coexistence}

Producers prefer to keep the adventitious presence of GM material in non-GM crops and products below the regulatory threshold to avoid the obligation to label products as GMOs. Thus, it is critical to develop and implement management and marketing practices to ensure that pollen drift or commingling do not result in adventitious presence of GMOs and that various systems of agriculture (traditional, GM, and organic) can coexist. ${ }^{218}$ For the European Commission, the term coexistence 'refers to the ability of farmers to make a practical choice between conventional, organic and GM-crop production, in compliance with the legal obligations for labelling and/or purity standards'.219

In a 2003 Recommendation, the Commission issued policy guidelines for coexistence. $^{220}$ The Commission did not require any particular type of policy instrument, but welcomed voluntary agreements, legislation, soft law, or a combination of these instruments, designed to 'achieve effective implementation, monitoring, evaluation, and control of the measures'. ${ }^{221}$ Commission guidelines, which apply 'from the seed to the silo', are nonbinding recommendations that address commercial seed and crop production, with a focus on technical segregation measures and economic consequences of admixtures of GM and non-GM crops. ${ }^{222}$ They are not measures to be adopted, but instead offer Member States general principles to apply and factors to consider in designing national measures. For example, the Commission suggested that management measures be based on the best available scientific evidence, which would permit cultivation of both GM and non-GM crops and ensure that adventitious presence of GM material in nonGM crops remains below labelling thresholds. Measures should emphasise farm-scale management and encourage cooperation and voluntary arrangements between farmers. Moreover, operators who introduce a new production type should be responsible for limiting gene flow, and farmers who plan to grow GM varieties should inform neighbours. In addition, the

\footnotetext{
Traces of Genetically Modified Seeds in other Products (2004) <http://www.saveourseeds.org/downloads/com_draft_seeds_04_2004.pdf> at 27 March 2009.

218 For details on coexistence, see Margaret Rosso Grossman, 'The Coexistence of GM and Other Crops in the European Union’ (2007) 16 Kansas Journal of Law and Public Policy 324.

219 Commission Recommendation 2003/556 on Guidelines for the Development of National Strategies and Best Practices to Ensure the Coexistence of Genetically Modified Crops with Conventional and Organic Farming [2003] OJ L189/36, 39.

220 Ibid.

${ }^{221}$ Ibid Annex § 2.1.8.

${ }^{222}$ Ibid Annex $\S 1.5$. The authorisation process considers health and environmental risks, which are not at issue for coexistence.
} 
Commission recommended production, harvest, and post-harvest practices to achieve coexistence. ${ }^{223}$

Thus, the European Community has not enacted regulatory measures for coexistence. Instead, the Commission has relied on subsidiarity ${ }^{224}$ to leave enactment of coexistence measures to Member States which, under Directive 2001/18, 'may take appropriate measures to avoid the unintended presence of GMOs in other products'. ${ }^{225}$ In April 2009, the Commission issued a report on coexistence, $^{226}$ which reviews the Commission's own activities ${ }^{227}$ and summarises Member State progress toward enactment of coexistence measures.

The Commission Report indicated that 15 Member States have adopted legislation for coexistence, and three others have notified the Commission of draft legislation. Measures vary among the States, but include mandatory training for producers who grow GM crops and notification of proposed GM crops to landlords, neighbours, those who share machinery, and even beekeepers. A GM crop register informs the public, though the level of detail required in Member States varies. Seed dealers may have obligations to report sales of GM seeds or to inform producers about coexistence rules. ${ }^{228}$

\footnotetext{
${ }^{223}$ Ibid Annex §§ 2-3.

${ }^{224}$ Subsidiarity, one of the principles governing the European Community, ensures that decisions are made as close to citizens as possible. 'In areas which do not fall within its exclusive competence, the Community shall take action, in accordance with the principle of subsidiarity, only if and in so far as the objectives of the proposed action cannot be sufficiently achieved by the Member States and can therefore, by reason of the scale or effects of the proposed action, be better achieved by the Community': EC Treaty, art 5.

${ }^{225}$ Directive 2001/18, art 26a(1), as amended by Regulation 1829/2003, art 43 [2003] OJ L 268/1.

${ }^{226}$ Commission, Report from the Commission to the Council and the European Parliament on the Coexistence of Genetically Modified Crops with Conventional and Organic Farming, COM (2009) 153 final (2 April 2009). The 2009 report indicates significant Member State progress since a 2006 report: Commission, Report on the Implementation of National Measures on the Coexistence of Genetically Modified Crops with Conventional and Organic Farming, COM (2006) 104 final (9 March 2006).

${ }^{227}$ For example, the Commission established the European Coexistence Bureau, to provide technical help with coexistence. In cooperation with Member States, the Bureau is developing crop-specific guidelines and best agricultural management practices for coexistence. A best practice document for maize production is expected by 2010: Commission, COM (2009) 153, above n 226, 4. See European Coexistence Bureau, Joint Research Centre, Home Page $<$ http://ecob.jrc.ec.europe.eu/> at 19 April 2009.

${ }^{228}$ Commission, COM (2009) 153, above n 226, 5-6. Though the Commission knew of no reports of economic damage, Member State liability rules, which are diverse, may eventually be relevant: at 9 .
} 
Twelve Member States have enacted technical segregation measures, normally expressed as isolation distances between GM and non-GM fields. Most national measures focus on maize, but some Member States specify distances for potato, sugar beet, and other crops. Buffer zones (pollen barriers, where crops must be treated as GM plants) may also be required. In six Member States, producers must follow stricter isolation distances between GM and organic fields than between GM and conventional crops. In general, the producer who grows GM crops bears responsibility for maintaining segregation measures. Some Member States have enacted measures to prevent commingling of GM and other crops during harvest, transport and storage, as well as during production. Coexistence measures in the majority of Member States are designed so that adventitious presence will not exceed the 0.9 per cent threshold for labelling, though a few States aim at the lowest possible level of admixture. ${ }^{229}$

Because only GM maize can be cultivated legally in the European Union, and few hectares are grown, Member States have little experience in monitoring the effectiveness of their coexistence measures. The Commission does not intend to propose Community coexistence rules. Instead, it will continue to provide research and guidance for coexistence. It recommends that Member State measures be assessed for effectiveness and efficiency and for their impact on producer competitiveness and freedom of choice for consumers and producers. $^{230}$

\section{EC Plans for Improved Implementation}

The European Community Directives and Regulations discussed here make up a comprehensive legal framework for authorisation of GMOs and their food and feed products. Nonetheless, questions about the effect of GMOs on health and the environment remain, and the European Council has called for improvements in implementation of the legislative measures discussed above. At the Environmental Council meeting in December 2008, the Council identified several important areas for improvement. ${ }^{231}$

The Council indicated that environmental assessment and monitoring of genetically modified plants should be strengthened. The Commission has asked EFSA to review its guidelines for environmental risk assessment,

\footnotetext{
${ }^{229}$ Ibid 6-7. Prohibitions of GM crops are not considered coexistence measures.

230 Ibid 10. The Commission's Report is accompanied by a Commission Staff Working Document, SEC (2009) 408 final, with detailed information about Member State coexistence measures.

${ }^{231}$ European Council, 'Council Conclusions on Genetically Modified Organisms (GMOs), 2912th Environment Council Meeting, Brussels’ (Press Release, 4 December 2008).
} 
particularly long-term environmental effects. That review should consider environmental consequences of changes in herbicide use in connection with herbicide-tolerant GMOs and examine the 'coherence' between risk assessments of GM plants that produce pesticides and of the pesticides themselves. ${ }^{232}$ The Council noted that Member State assessment practices should be harmonised, and that new procedures should ensure that GMOs are monitored effectively after commercialisation. Moreover, the Council would like an assessment of the socio-economic benefits and risks of GMOs, which can be considered in risk management. Member State information about socio-economic effects should lead to a Commission report to Council and Parliament. The Council emphasised the important role of Member States in the assessment of GMOs for cultivation and encouraged the more effective and transparent use of scientific expertise in assessing risks of cultivation of GMOs or their use in food and feed. ${ }^{233}$

The Council noted that the Commission will complete a study on the establishment of seed thresholds and reaffirmed the need for labelling thresholds for the adventitious presence of GMOs in conventional seeds. The Council insisted that thresholds should be 'at the lowest practicable, proportionate and functional levels for all economic operators, [and] must contribute to ensuring freedom of choice to producers and consumers of conventional, organic and GM products alike'. ${ }^{234}$ The Council invited the Commission to set those thresholds as soon as possible, using current scientific information.

Finally, the Council focused on regional and local characteristics of Member States. The Council recognised the possibility, consistent with the precautionary principle, ${ }^{235}$ of imposing restrictions, or even prohibitions, on GMOs in fragile ecosystems, and especially protected natural habitats. The Council reminded Member States of their right to enact national measures to ensure coexistence of GM and other crops. The Council also noted that GMOfree zones could be created by voluntary agreement of farmers, but that freedom of choice requires all farmers in the region to be informed about the plan to create a GMO-free zone. ${ }^{236}$

\footnotetext{
${ }^{232}$ Ibid 2. Plant protection products are governed by Council Directive 91/414 Concerning the Placing of Plant Protection Products on the Market [2001] OJ L 230/1, as amended. Consolidated text: CONSLEG 1991L0414-01/01/2004.

${ }^{233}$ European Council, above n 231.

${ }^{234}$ Ibid 4.

${ }^{235}$ On the precautionary principle, see the discussion in Part IVC of this article.

${ }^{236}$ European Council, above n 231, 5.
} 


\section{Authorisation IN THE United States AND the EUROPEAN COMMUNITY: A COMPARISON}

\section{A Attitudes toward GMOs}

Attitudes towards GM crops and foods differ significantly in the United States and the European Community, and those attitudes may influence aspects of the regulatory process. Government policy in the United States is generally positive toward GMOs and poses few obstacles to their widespread cultivation and consumption. The European Community officially favours GMOs, ${ }^{237}$ too, though a Commission report indicated that 'the EU is often not at the forefront of development, eg in ... GM crops' ${ }^{238}$ Despite official policy, and in violation of EC law, several Member States and numerous regions have banned cultivation of GM crops.

Moreover, attitudes of producers and consumers contrast. In the United States, producers favour GMOs, as evidenced by statistics indicating that the majority of corn, soybean, and cotton hectares are GM. ${ }^{239}$ In the European Community, where only GM maize can be cultivated and few producers actually grow the GM maize, many farmers are dubious about GM crops. Yet in some Member States, farmers are eager to grow GM crops; in Denmark, for example, farmers would like to grow GM maize and a GM potato. ${ }^{240}$

Similarly, most consumers in the United States seem to have positive or, at worst, neutral attitudes towards GMOs. Though consumers are not always well-informed about GM food products, few avoid GM foods or express concerns about the safety of biotech food, and a majority would buy GM foods. ${ }^{241}$ Until recently, however, US consumers have faced few food safety issues, and most consumers have little reason to mistrust the federal agencies that regulate GMOs. In contrast, the BSE crisis ${ }^{242}$ and other food crises in Europe have triggered consumer mistrust of government and even science, so consumer hesitation about GMOs, even in the face of comprehensive regulation, is not surprising. Consumers have continued to trust NGOs,

\footnotetext{
${ }^{237}$ Commission, above $\mathrm{n} 11$.

${ }^{238}$ Eleni Zika et al, Consequences, Opportunities and Challenges of Modern Biotechnology for Europe (JRC Report EUR 22728, 2007) 8.

${ }^{239}$ See generally James, above $\mathrm{n} 2$.

240 'Danish Farmers to Grow GM Crops' (2008) GMO Compass <http://www.gmo-compass. org/eng/news/383.docu.html> at 14 October 2009 (citing a report in The Copenhagen Post).

${ }^{241}$ International Food Information Council, above n 10, 2008 Topline Data.

${ }^{242}$ For more information on BSE, see Margaret Rosso Grossman, 'Animal Identification and Traceability under the US National Animal Identification System’ (2006) Journal of Food Law and Policy 231, 235-41.
} 
including Greenpeace, ${ }^{243}$ an organisation that opposes GMOs. One scholar suggested that 'GM politics in the EU can be understood partially as a defensive strategy of authorities to regain credibility with the public .... 244 Even with stringent regulation, however, consumer scepticism and opposition remain. In several EC Member States (for example, France, Germany, and others), vandals have destroyed field trials of GM crops, a situation that may have led to prohibition of GM research in two German universities. ${ }^{245}$

\section{B Regulatory Requirements}

\section{Regulatory Approaches}

Both the United States and the European Community regulate GMOs and GM foods to protect public health and the environment (including agriculture). The regulatory approaches, however, differ in a number of important respects. Earlier Parts of this article provide details, and the discussion below highlights a few significant differences.

In the United States, the approach to GMOs can be characterised, in general, as product-oriented. That is, the focus is on the product itself, rather than the process (genetic modification) by which it was created. As a result, the United States has relied on existing statutes, instead of enacting new laws specifically designed for GMOs. Under those existing laws, however, some GM products may escape comprehensive review; the concepts of substantial equivalence and GRAS, discussed above, are examples. In the United States, statutory amendments, new regulations, and agency guidelines adopted since the 1980s have applied to GMOs and their products.

In contrast, the European Community adopted a process-oriented regulatory approach, which focuses on the process by which the new variety was created. Under the European Community's process-oriented regulatory approach, of course, each product is regulated, but the process of genetic modification triggers a careful look at the product. The European Community's focus on

\footnotetext{
${ }^{243}$ See Bernd van der Meulen, 'The EU Regulatory Approach to GM Foods' (2007) Kansas Journal of Law and Public Policy 286, 297-8. Greenpeace 'opposes the release of GMOs into the environment as there is not adequate scientific understanding of their impact on human health and the environment. GMOs pose unpredictable and irreversible long-term risks': Greenpeace European Unit, Sustainable Agriculture and GMOs $<$ http://www.greenpeace.org/eu-unit/campaigns/say-no-to-genetic-engineering> at 11 May 2009.

${ }^{244}$ van der Meulen, above n 243, 297.

${ }^{245}$ Henry I Miller, Auf Wiedersehen, agbiotech (Letter to the Editor) (2008) 26(9) Nature Biotechnology 974.
} 
the process of genetic modification led to enactment of measures designed for GMOs, beginning in 1990. The approval process in the European Union is complex and can take twice as long as the procedure in the United States and some other nations. ${ }^{246}$

The allocation of regulatory responsibility differs. In the United States, federal law governs authorisation of GMOs and their products, and federal regulations and guidelines provide detailed requirements for authorisation. Federal agencies (the USDA, FDA and EPA) implement those laws and regulations. Though states receive information, and some states impose other requirements, states do not play a role in the authorisation process. Instead, the process is more centralised. Moreover, few states have acted to ban or restrict the cultivation of GM varieties.

In the European Community, however, Member States play a significant role. The authorisation process starts with an application to the Member State competent authority, and Member States have other responsibilities (for example, establishing a register of GM releases). Member States implement Directive 2009/41 (recasting Directive 90/219) on contained use and, acting through their competent authorities, authorise releases for field tests and research under Directive 2001/18. Though Member States can authorise a GMO for placing on the market, objections from other States trigger a Community procedure. Under Regulation 1829/2003 on food and feed, Member States play a role, but EFSA's significant responsibilities under that Regulation make the process more centralised. As the discussion above indicates, EC law provides safeguards for Member States with scientific reasons for preventing cultivation of GM crops, and several States have used those safeguards to ban cultivation of GM maize.

In the United States, regulation of GMOs is rather sectoral; applicable law and regulations are related to the sector (for example, agriculture, environment, food) in which the GMO or its product will be used. Agencies with expertise in that sector implement the authorisation process. These agencies coordinate their activities to avoid asynchronous authorisation; that is, the USDA will not usually deregulate a GM variety until the applicant has consulted with the FDA on food and feed uses.

In the European Community, early legislation was more horizontal (that is, not related to the proposed use of the GMO or its product), but the enactment of Regulation 1829/2003 on food and feed took a more sectoral approach. Nonetheless, the likelihood that both a GMO and its food and feed products

${ }^{246}$ Gé Backus et al, EU Policy on GMOs: A Quick Scan of the Economic Consequences (LEI Report 2008-070, October 2008) 7. 
will be authorised adds complexity because both horizontal measures (for example, the Directives for contained release and deliberate release) and sectoral measures (for example, Regulation 1829/2003) will apply. The one door-one key procedure mentioned above helps to make the authorisation process more efficient.

\section{$2 \quad$ Labelling}

Another significant difference between US and EC regulation of GMOs and their products relates to labelling. Labels facilitate traceability, and labels on food products provide information to consumers. When GM food is at issue, consumer interest may reflect ethical preferences that go beyond issues of health and safety. ${ }^{247}$ In the United States, labels are generally not required for GMOs or their products. The FDA does not consider most GM foods to be materially different from their conventional counterparts and has therefore not required labels, despite some consumer demand. Labels can be required, however, if GM foods differ significantly from their conventional counterparts and raise health or ethical issues.

In the European Community, GMOs and their products must be labelled if GM content exceeds the rather low ( 0.9 per cent) threshold of GM content. Moreover, to avoid labelling, the GM content below that threshold must be adventitious or technically unavoidable. In Europe, where consumers have expressed strong concerns about GM food, labels seem to be an important component of the consumer's right to choose. ${ }^{248}$ In a study on consumer behaviour in 10 Member States concluded in 2008, however, researchers found that 'most shoppers did not actively avoid GM products, suggesting that they are not greatly concerned with the GM issue'. ${ }^{249}$ Consumers do want freedom of choice, but in the context of that freedom, 'GM-products offered for sale are indeed purchased'. ${ }^{250}$

\footnotetext{
${ }^{247}$ See Peter H Sand, 'Labelling Genetically Modified Food: The Right to Know' (2006) 15 Review of European Community and International Environmental Law (RECIEL) 185, 186. Sand notes that at least 20 other countries require labels, albeit with different thresholds: at $186-7$.

${ }^{248}$ On labelling in the context of the WTO, the Cartagena Protocol on Biosafety, and Codex Alimentarius, see ibid.

${ }^{249}$ Vivian Moses et al, Do European Consumers Buy GM Food? (Final Report, European Commission Project No 518435, 14 October 2008) 1-9 - 1-10.

${ }^{250}$ Ibid 1-10.
} 


\section{Exercise of Precaution}

One perceived difference between regulation of GMOs and their products in the United States and Europe appears in the application of the precautionary principle. The precautionary principle ${ }^{251}$ indicates that, in situations where scientific uncertainty exists, that lack of certainty should not delay adoption of preventive measures. ${ }^{252}$ The EC Treaty adopted the precautionary principle as a guiding principle of environmental law, ${ }^{253}$ implemented in measures that affect the environment, agriculture, and food safety (as well as other areas). Decisions of the European Court of Justice have applied the principle in cases involving risk assessment and risk management. ${ }^{254}$ Although the United States has not adopted the principle formally, the United States takes a precautionary approach to food safety and the environment. US statutes and regulations often require precaution, and court decisions implement these requirements.

EC regulation of GMOs invokes the precautionary principle explicitly (for example, in Directive 2001/18 and Regulation 1830/2003), ${ }^{255}$ while US regulatory measures do not refer to the principle. Nonetheless, in both the European Community and the United States, precaution plays a role in regulatory measures that ensure that GMOs and their products do not compromise food safety or harm the environment.

Both regulatory systems require risk assessments, which rely in part on information provided by the applicant, for release of GMs into the environment. In the European Community, field trials and marketing of GM products require full environmental risk assessments. In the United States, large-scale field trials trigger risk assessment by the USDA and (for PIPs) by

\footnotetext{
${ }^{251}$ A commonly cited formulation of precaution appears in the Rio Declaration on Environment and Development, Prin 15, UN Doc A/Conf 151/5/Rev 1 (14 June 1992), reprinted in 31 ILM 874, 879: '[T]o protect the environment, the precautionary approach shall be widely applied by States according to their capabilities. Where there are threats of serious or irreversible damage, lack of full scientific certainty shall not be used as a reason for postponing costeffective measures to prevent environmental degradation.'

252 See Nicolas de Sadeleer, 'Origin, Status and Effects of the Precautionary Principle' in Nicolas de Sadeleer (ed), Implementing the Precautionary Principle: Approaches from the Nordic Countries, EU and USA (2007) 3.

${ }^{253}$ EC Treaty, art 174(2).

${ }^{254}$ See Helle Tegner Anker and Margaret Rosso Grossman, 'Authorization of Genetically Modified Organisms: Precaution in US and EC Law' (2009) European Food and Feed Law Review 3, 9-11 (discussing ECJ decisions).

${ }^{255}$ Regulation 2001/18, art 1 [2001] OJ L 106/1; Directive 1830/2003, preamble (3) [2003] OJ L 268/24. Though Regulation 1829/2003 does not mention the principle specifically, it refers to the General Food Law, Regulation 178/2002, art 7(1) [2002] OJ L 31/1, which does invoke the principle.
} 
the EPA, but some less risky GMOs and small-scale field trials get less stringent oversight. In the European Community, all GM foods are subject to a stringent environmental risk assessment with a focus on human health and environment. In the United States, the concept of substantial equivalence means that most GM foods, which do not differ significantly from their nonGM counterparts, are not assessed. Most non-pesticidal GMOs are generally recognised as safe (GRAS) and are not regulated as food additives. Yet these foods do not escape scrutiny; voluntary consultations with the FDA ensure review. ${ }^{256}$

Risk management, which relies on data from risk assessment, determines whether a GMO or GM product will be authorised and, if so, whether special risk management measures are required. To protect the environment, both the United States and the European Union condition authorisation on the absence of adverse effects - for example, the absence of adverse effects on health or environment (EC) or the likelihood that GMOs or GM products will not pose a plant pest risk or cause unreasonable adverse effects on the environment (US). The European Community, however, requires post-market monitoring of GMOs, a precaution not yet required in the US. In the European Community, no GM food can be authorised until the absence of adverse effects has been demonstrated, and post-market monitoring follows authorisation. In the United States, however, the FDA does not formally authorise most new GM foods, nor does the EPA require food residue tolerances for most PIPs. Thus, though both the European Community and the United States apply precautionary standards in assessing the risk of GMOs and their products, the EC carries the precaution beyond authorisation into the marketplace. Therefore 'the role of precaution in risk management appears to be stronger in the EC than in the US'. ${ }^{257}$

\section{CONCLUSION}

In the years since the United States published its Coordinated Framework for Regulation of Biotechnology and the European Community enacted its earliest Directives to govern GMOs, numerous GM crops and their products have been commercialised. Farmers began to plant those crops in 1996, and steady increases in GM production have occurred. The 2008 global market value (sale of seed plus technology fees) of GM crops was estimated at US \$7.5 billion and is projected to be US $\$ 8.3$ billion in 2009. Further increases in GM production are expected. Additional countries may cultivate GM crops, and

\footnotetext{
${ }^{256}$ Anker and Grossman, above n 254, 14-17.

${ }^{257}$ Ibid 14, 18-20.
} 
the number of farmers planting biotech crops may increase significantly, especially in developing countries. New GM crops and traits will also expand production. ${ }^{258}$

Many commercialised GM crops were developed in the United States and authorised under the regulatory system described in this article. They are cultivated and consumed in the United States and in other nations. Under the lengthy approval process in the European Community, fewer GM varieties have been authorised for food, feed, or processing uses there, and only GM maize is authorised for cultivation. Thus, not all GMOs approved in the United States can be imported into Europe. Moreover, because the EU food industry is reluctant to market GM food products, most GM products sold in Europe (primarily soy and maize) are used for animal feed. ${ }^{259}$

This situation of asynchronous approvals and the European Community's strict prohibition of imports of GMOs not yet approved in the EC has engendered conflict. Two issues, discussed in reports written in Europe - one by a research group and the other by the European Commission itself illustrate this conflict.

One issue is the availability of livestock feed. In 2007, the EU Commissioner for Agriculture and Rural Development noted that European reluctance to import GM livestock feed increased the cost of feed for pigs and poultry and could threaten the livestock industry. ${ }^{260}$ A 2008 Dutch study corroborated this statement. ${ }^{261}$ The European livestock industry, which imports about 77 per cent of protein feed, depends on imported soy and maize products. Zero tolerance of unapproved GMOs means that livestock producers face higher costs for non-GM soy, and in some cases producers may not be able to import protein-rich feedstuffs. The lack of feed ingredients will affect the competitiveness of European Union livestock production, and 'European livestock operators will lose market share in domestic and world markets to foreign competitors' ${ }^{262}$ Because livestock production is about 40 per cent of total EU agricultural production, loss of market share will have significant financial implications.

\footnotetext{
${ }^{258}$ James, above $\mathrm{n} 2$.

${ }^{259}$ Commission, Report, above n 201, 2.

${ }^{260}$ James Kanter, 'European Official Faults Ban on Genetically Altered Feed', The New York Times (New York), 27 November 2007.

${ }^{261}$ Backus et al, above n 246, 54. The study identified problems, including disruptions of trade, caused by asynchronous EC approval of GM crops and its zero tolerance threshold.

${ }^{262}$ Ibid 55.
} 
Similar issues, focused on importing non-GM raw materials, will face the food industry if it becomes more hospitable to GM foods. ${ }^{263}$ The Dutch study concludes 'that it is likely that in the near future problems will become more urgent. This could negatively affect the EU supply of raw materials and economic position of the European agricultural and food sector' ${ }^{264}$

In addition, EC requirements for traceability and labelling (especially in Regulation 1830/2003) impose burdens on trading partners. According to a Commission report, Member States believe that traceability and labelling help to achieve 'more informed choice, more efficient prevention of deceptive practices and better official controls'. ${ }^{265}$ Research indicates that traceability helps to foster confidence in food safety and to encourage sale of non-GM products. $^{266}$ From a different point of view, however, exporters who cannot sell GM products claim that, as a result, potential buyers are forced to buy more expensive non-GM products. Exporters find labelling thresholds arbitrary and 'claim that labelling products produced from GMOs, where no GM material can be detected, places an unfair burden on operators in the food and feed sector'. ${ }^{267}$ The Commission disagrees, however, and believes that 'consumer demand for non-GM products, higher prices in the feed sector and asynchronous approval for GMOs between countries' have affected trade more significantly. ${ }^{268}$ These different viewpoints highlight the controversy about the impact of EC traceability and labelling requirements.

Both the United States and the European Community authorise GMOs and their products under comprehensive regulatory schemes, intended to ensure that GMOs do not harm health, the environment, or agriculture. Opinions differ about the effectiveness of regulatory oversight, of course, but both regulatory schemes allow a GM variety that meets regulatory requirements to be authorised. Though EC regulatory measures seem more complex than those in the United States, differences in legal requirements, by themselves, do not seem to account for the European Community's hesitation to allow cultivation of additional GMOs or the limited number of varieties authorised for feed and food use. Instead, underlying attitudes of producers and

\footnotetext{
263 Ibid.

${ }^{264}$ Ibid 56.

${ }^{265}$ Commission, Report, above n 201, 7.

${ }^{266}$ Ibid 3 (citing Eurobarometer 64.3, Europeans and Biotechnology in 2005: Patterns and Trends).

${ }^{267}$ Commission, Report, above n 201, 7. Furthermore, '[o]ne overseas association expressed concern at the fact that EU food processors and retailers had stopped using soybean oil from the US, because the resulting food and feed products would be labeled as GM even if no DNA from the modification appears in the oil, and deplored the fact that such products required labelling': at 4.

${ }^{268}$ Ibid 7.
} 
consumers, as well as political considerations, may help to explain many of the contentious issues raised by GMOs and the reluctance of the European Union to embrace GM technology. 